US Army Corps

of Engineers ${ }_{\circledast}$

Engineer Research and

Development Center

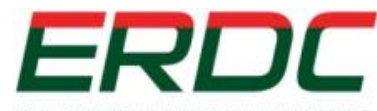

INNOVATIVE SOLUTIONS

for a safer, better world

\title{
Climate Change Vulnerability of Army Installations Attributable to Listed and At-Risk Species
}

Matthew G. Hohmann, David K. Delaney, and Wade A. Wall

July 2017
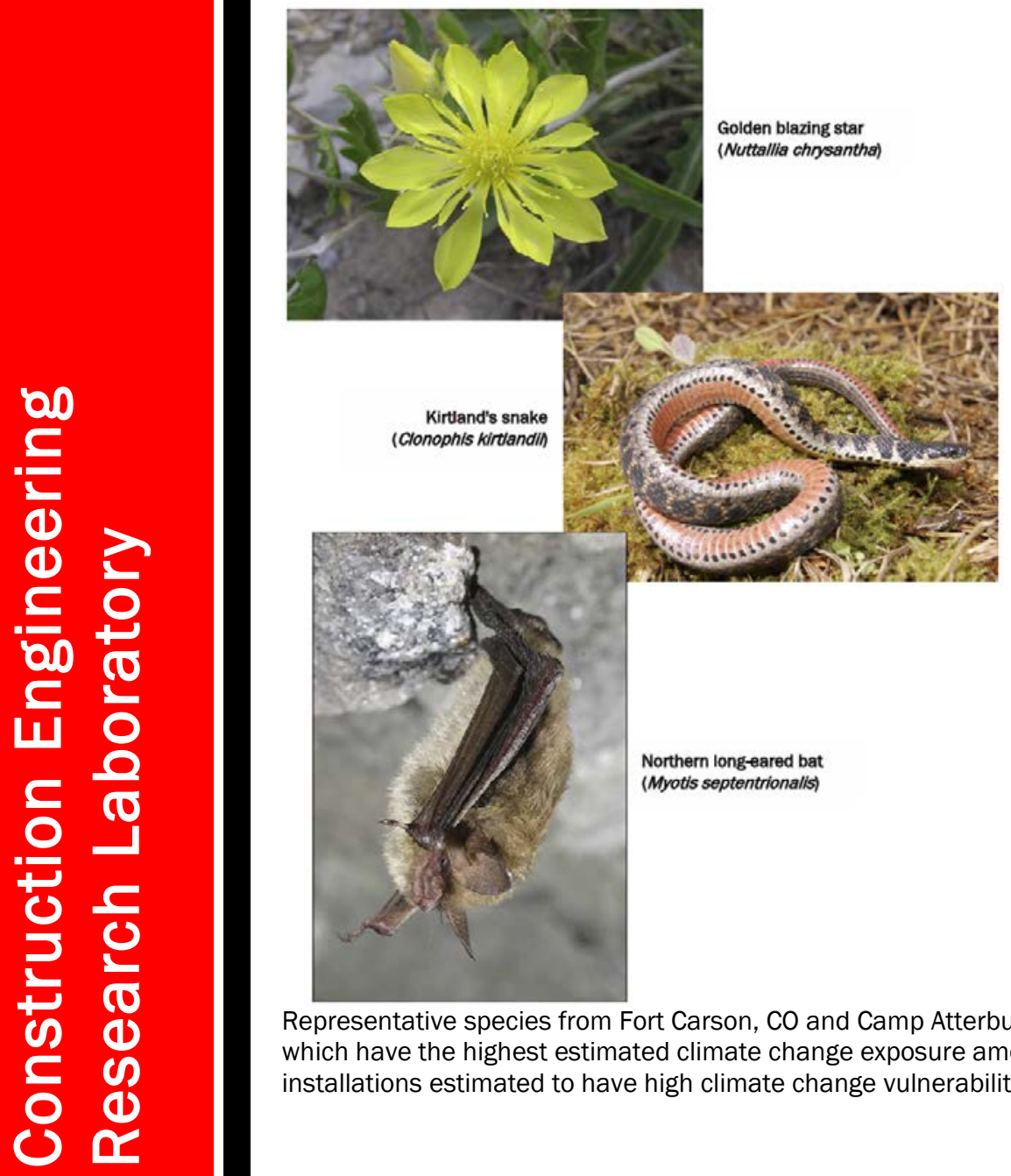

Representative species from Fort Carson, CO and Camp Atterbury, IN, which have the highest estimated climate change exposure among installations estimated to have high climate change vulnerability 
The U.S. Army Engineer Research and Development Center (ERDC) solves the nation's toughest engineering and environmental challenges. ERDC develops innovative solutions in civil and military engineering, geospatial sciences, water resources, and environmental sciences for the Army, the Department of Defense, civilian agencies, and our nation's public good. Find out more at www.erdc.usace.army.mil.

To search for other technical reports published by ERDC, visit the ERDC online library at http://acwc.sdp.sirsi.net/client/default. 


\section{Climate Change Vulnerability of Army Installations Attributable to Listed and At-Risk Species}

Matthew G. Hohmann, David K. Delaney, and Wade A. Wall

U.S. Army Engineer Research and Development Center (ERDC)

Construction Engineering Research Laboratory (CERL)

2902 Newmark Dr.

Champaign, IL 61826

Final Report

Approved for public release; distribution is unlimited.

Prepared for Office of the Assistant Secretary of the Army for Acquisition, Logistics, and Technology, Washington, DC 20310-0103

Under Program Element 622720A896, Work Unit F94KF0, "Maneuver Area Capacity" 


\section{Abstract}

Climate change is an important emerging concern for the U.S. Department of Defense (DoD) and the Army. Key among the issues is climate changedriven increases in the number of species listed under the U.S. Endangered Species Act (ESA) and stress to Federally listed species already listed, because both pose additional management requirements and challenges, as well as potential restrictions on training land use. This work developed an approach for characterizing this component of installation climate change vulnerability that integrates multiple factors related to exposure, sensitivity, adaptive capacity, and number of listed and at-risk species. The approach was applied to Army installations in the Continental United States that have Integrated Training Area Management (ITAM) programs. Additionally, the assessment was used to rank installations across the Army based on the aggregate vulnerabilities of species. The approach to vulnerability assessment demonstrated here is suitable for evaluating whether climate change-driven impacts to listed and at-risk species is likely to affect installation resilience.

DISCLAIMER: The contents of this report are not to be used for advertising, publication, or promotional purposes. Citation of trade names does not constitute an official endorsement or approval of the use of such commercial products. All product names and trademarks cited are the property of their respective owners. The findings of this report are not to be construed as an official Department of the Army position unless so designated by other authorized documents. 


\section{Contents}

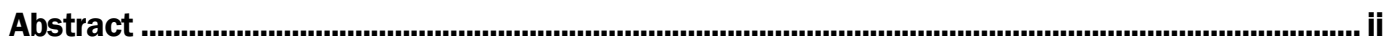

Tables and Figure...........................................................................................................................iv

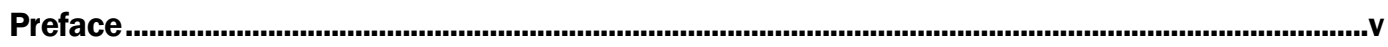

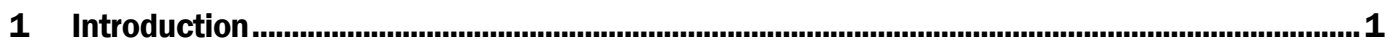

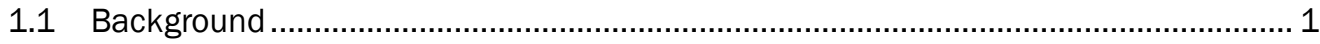

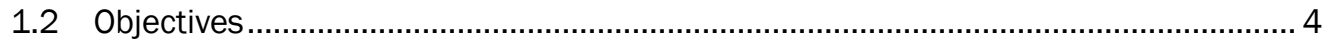

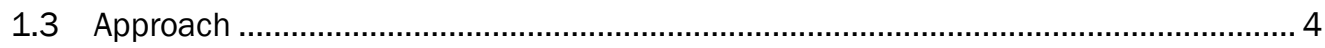

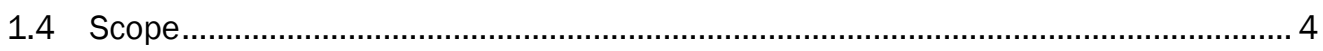

2 Methods .............................................................................................................................................. 5

2.1 Climate change vulnerability assessment........................................................ 5

2.2 Direct and indirect climate change exposure .................................................. 7

2.3 Climate change sensitivity.................................................................................. 8

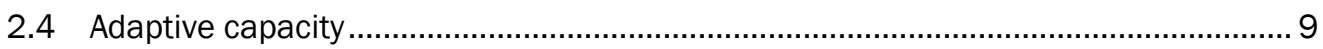

2.5 Listed and at-risk species........................................................................... 11

2.6 Installation ranks ...................................................................................... 12

2.7 Calculating climate change vulnerability scores for installations ............................. 12

2.8 Examining differences in installation climate change vulnerability factors

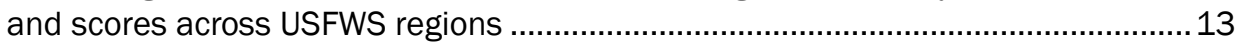

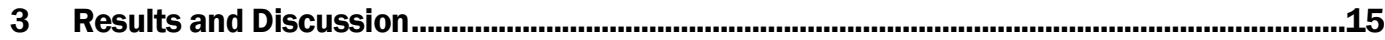

3.1 Direct and indirect exposure ..................................................................... 15

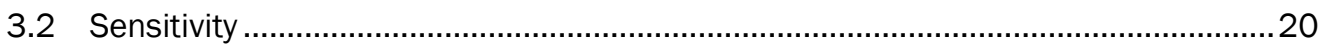

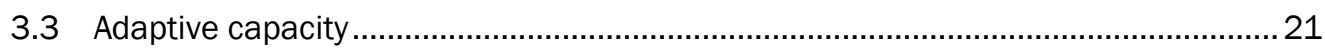

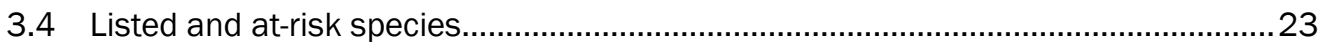

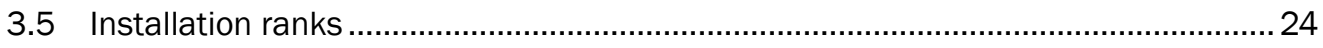

3.6 Threatened and endangered species related climate change vulnerabilities of installations ............................................................................................ 24

4 Conclusions and Recommendations .........................................................................................26

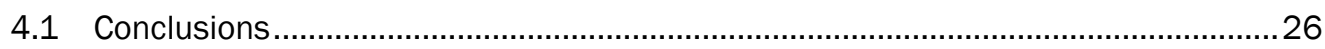

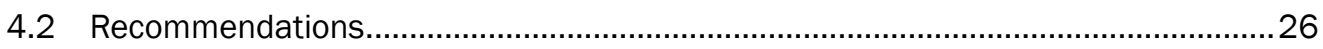

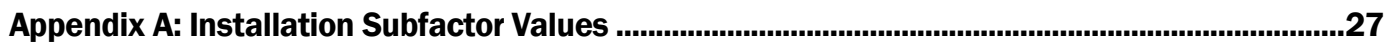

Appendix B: Lists of Threatened, Endangered, and At-Risk Species by Installation ....................31 Appendix C: Installation Vulnerabilities Calculated Without the Installation Rank

Factor ...........................................................................................................................................44

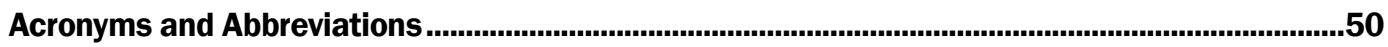

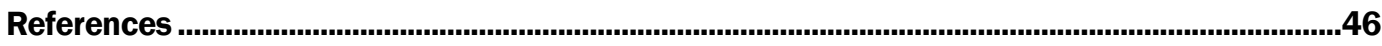

Report Documentation Page (SF 298) .................................................................................................52 


\section{Tables and Figure}

\section{Tables}

1 Factors and subfactors used to assess climate change vulnerability................................. 6

2 Probability of Federal listing by taxonomic group used to weight species at-risk. Numbers in parentheses represent number of species used to develop the model.

3 Weights multiplied by the five factors to calculate climate change vulnerabilities of Army ITAM installations .

4 USFWS regions and associated states.

5 Weighted scores for five factors used to estimate climate change vulnerability of 43 CONUS Army ITAM installations. Installations are ordered high-to-low based on vulnerability.

6 Mean scores and ranges (in parentheses) for five climate change factors and the overall vulnerability of 43 CONUS Army ITAM installations within seven USFWS regions. Means designated by the same letter within columns do not differ at $P=$ 0.05 by Tukey's Honestly Significant Difference in an across-region comparison

\section{Figure}

1 Conceptual diagram of combinations of climate change exposure, sensitivity, and adaptive capacity that identify seven classes of vulnerability having different implications for prioritization and strategic planning 


\section{Preface}

This study was conducted for Office of the Assistant Secretary of the Army for Acquisition, Logistics, and Technology, ASA(ALT) under program element 622720A896, "Army Environmental Quality Technology"; Work Unit F94KF0, "Maneuver Area Capacity." The technical monitor was Steve Sekscienski, OACSIM-ISE.

This work was conducted by the Ecological Processes Branch (CNN), Installations Division (CN), Engineer Research and Development Center, Construction Engineering Research Laboratory (ERDC-CERL). Dr. Chris Rewerts was Chief, CEERD-CNN, and Michelle J . Hanson was Chief, CEERD-CN. The associated Technical Director was Alan Anderson, CEERD-CZT. The Deputy Director of ERDC-CERL was Dr. Kirankumar Topudurti and the Director was Dr. Ilker Adiguzel.

COL Bryan S. Green was Commander of ERDC, and Dr. David W. Pittman was the Director. 
THIS PAGE INTENTIONALLY LEFT BLANK 


\section{Introduction}

\subsection{Background}

Federal land management agencies are faced with the challenge of managing numerous threatened, endangered, and at-risk species (i.e., taxa assessed by NatureServe as critically imperiled [G1/T1] or imperiled [G2/T2]) (NatureServe 2011), a challenge that will be exacerbated by climate change (Dawson et al. 2011, Ellenwood et al. 2012, Shaw et al. 2021, Urban 2015). The U.S. Department of Defense (DoD), which is the fifth largest land management agency in the United States, manages over 12 million hectares of land on more than 425 military installations (Stein et al. 2008). Although this represents less than $5 \%$ of the land managed by the four larger agencies combined, 23\% of all U.S. Endangered Species Act (ESA) status (endangered, threatened, candidate, or proposed species) and $15 \%$ of all at-risk species occur on DoD lands (Stein et al. 2008).

Additionally, more of these DoD ESA status (270; ACSIM 2010) and atrisk species (220; NatureServe 2011) occur on Army lands than occur on all other DoD services combined (Stein et al. 2008). Given the recent U.S. Fish and Wildlife Service (USFWS) lawsuit settlement requiring review of 757 species proposed for listing under the ESA by 2018 (ESA Section 4 Deadline Litigation, Case Number 2165, U.S. District Court for the District of Columbia), a substantive number (ca. 230) of additional listed species are anticipated to occur on/ near Army and Army National Guard installations (Sperry et al. 2016). The currently large and increasing Army conservation responsibility related to Federally listed and at-risk species highlights the importance of proactively conducting climate change vulnerability assessments.

Executive Order (EO) 13514, Federal Leadership in Environmental, Energy and Economic Performance (White House 2009) required Federal agencies to address climate change risks and vulnerabilities in short- and long-term planning. DoD first acknowledged the potential impacts of climate change on its facilities, infrastructure, military capabilities, and training and testing activities within the 2010 Quadrennial Defense Review (DoD 2010). Subsequently, DoD issued Department of Defense Instruction (DODI) 4715.03 (DoD 2011) pertaining to its Natural Resources 
Conservation Program, which requires DoD installations to: (1) address climate change in their Integrated Natural Resources Management Plans (INRMPs), (2) use the best available science to assess potential climate change impacts, and (3) use adaptive strategies to address those impacts. In 2013, this Instruction was followed by Department of Defense Manual (DODM) 4715.03, the Integrated Natural Resources Management Plan Implementation Manual (DoD 2013), which outlined procedures for preparing, reviewing, updating, and implementing INRMPs in accordance with Department of Defense Instruction (DODI) 4715.03.

In response to EO 13514, DoD also developed a Climate Change Adaptation Roadmap (CCAR) in 2012 (DoD 2012). The CCAR fulfilled a requirement to include an adaptation planning document as an appendix to the Department's annual Strategic Sustainability Performance Plan. The CCAR established broad climate change adaptation goals to: (1) develop a coordinating committee to address climate change, (2) use the best available science to inform decisions, (3) integrate climate change information into existing processes, and (4) encourage partnerships with other agencies (DoD 2012). Given that impacts to DoD are expected to vary by region, assessing vulnerability to climate change is a large component of the CCAR framework. The CCAR included a detailed table highlighting specific climate change phenomena, potential impacts, and potential mission vulnerabilities. Among the listed potential impacts are stress to protected species and an increase in the number of species at risk.

In 2013, EO 13653, Preparing the United States for the Impacts of Climate Change (White House 2013), charged DoD and other Federal agencies to:
complete an inventory and assessment of proposed and completed changes to their land- and water-related policies, programs, and regula- tions necessary to make the Nation's watersheds, natural resources, and ecosystems, and the communities and economies that depend on them, more resilient in the face of a changing climate.

It also charged DoD and other Federal agencies to "develop and provide authoritative, easily accessible, usable, and timely data, information, and decision-support tools on climate preparedness and resilience." EO 13653 also mandated regular updates to and implementation of the agency adaptation plans required under EO 13514. 
In 2014, DoD updated its CCAR in response to requirements set out in EO 13653 (DoD 2014a). In alignment with EO 13653, the updated CCAR established three broad adaptation goals: (1) to identify and assess the effect of climate change on the Department, (2) to integrate climate change considerations across the Department and manage associated risks, (3) to collaborate with internal and external stakeholders on climate change challenges. Each of these goals was evaluated in relation to DoD's plans and operations, training and testing, built and natural infrastructure, and acquisition and supply chain. Additionally, a summary of the potential impacts to DoD's mission was provided within Annex 2 of the 2014 CCAR. Similar to the 2012 roadmap, the 2014 CCAR explicitly identified concerns about climate change-related stress to currently listed threatened and endangered species on and adjacent to DoD installations. Increased numbers of listed and at-risk species and associated management requirements and challenges were also identified as concerns.

The Army needs a means of identifying the impact of future climate change on installations, to generate information about long-term sustainability that can be used to make diverse decisions, such as training mission assignments, base realignment and closure (BRAC), conservation funding investments, and alternative mitigation strategy selection. Wilhoit et al. (2015) proposed a simple method of ranking installations based on potential impacts of climate change-related listed and at-risk species management on training land use. However, their approach did not include any specific information about climate change vulnerability, but instead used the number of species on installations, the conservation status of these species (i.e., Federally listed, proposed for listing, and at-risk), listing probabilities of different taxonomic groups, and installation area. Effectively, their ranking metric calculated a status and probability of listingadjusted estimate of at-risk and listed species density.

In BRAC studies, the Army ranks installations based on their characteristics. For example, since installation training lands provide the Army with critical mission capabilities, installations with the largest training lands are considered high value. Anything that erodes the size of the available training lands or the use of those lands, negatively impacts the installation's value and is of interest. Climate change is one phenomenon that can erode multiple installation characteristics and thus the installation's resulting value to the Army. 
This effort adopted an expanded approach for characterizing the anticipated relative increase in climate change-related conservation responsibilities among installations, one that specifically incorporates climate change vulnerability.

\subsection{Objectives}

The objectives of this effort were to:

1. Develop an approach for assessing installation climate change vulnerabilities due to listed and at-risk species

2. Implement this climate change vulnerability assessment for Continental United States (CONUS) Army installations included within the Integrated Training Area Management (ITAM) program

3. Use the estimated vulnerabilities to rank installations across the Army

4. Explore the variable contribution of the five factors used to estimate climate change vulnerability

5. Make recommendations about mitigation strategies.

\subsection{Approach}

The objectives of this work were accomplished in five primary tasks:

1. The listed and at-risk species occurring on each Army installation were identified.

2. Spatial and aspatial datasets for five factors used to assess the climate change vulnerability of species were developed.

3. The developed assessment approach was implemented.

4. Climate change vulnerabilities across installations and regions were compared.

5. Recommendations about suitable mitigation strategies based on the magnitudes of the evaluated factors were summarized.

\subsection{Scope}

The climate change vulnerability assessments within this effort focused on CONUS installations and species that have been either Federally listed as threatened or endangered, or that have been identified to be at-risk (NatureServe 2014). Assessments were made using climate change projection data for the year 2050 . 


\section{Methods}

Climate change vulnerability is generally described as a function of exposure, sensitivity, and adaptive capacity (Schneider et al. 2007, Williams et al. 2008). Exposure is characterized by the magnitude and rate of climate change a region is expected to experience. Different portions of the United States are projected to vary in their direct and indirect exposure to climate change. Sensitivity to climate change is characterized by the degree to which a species or region is anticipated to be affected by climate variables (e.g., drought, extreme temperatures). Regions where substantial annual or interannual climate variability occurs are anticipated to be less susceptible to climate change. Adaptive capacity refers to the ability of species to adapt to climate change and to the availability of mitigation options (e.g., conservation partners and natural landscapes) that might lessen climate change impacts in a region.

\subsection{Climate change vulnerability assessment}

Multiple approaches for estimating species' and regional climate change vulnerabilities have been proposed and adopted (e.g., USEPA National Center for Environmental Assessment framework, USEPA 2009; NatureServe's Climate Change Vulnerability Index, Young et al. 2011, 2015; Bagne et al. 2011). This effort set out to develop an approach for quantifying the degree to which Army installations may be affected by climate change as a result of increased vulnerability of listed and at-risk species, which can restrict training and testing land access due to requirements of the ESA. Specifically, this work sought an approach that was objective, uncomplicated, transparent, and applicable across the Continental United States, and that could be estimated using available spatial datasets. It is also important to examine multiple components of risk in combination when assessing the potential impacts of climate change on species of concern (see Hinkel 2010, Dickinson et al. 2014). The approach ultimately adopted was based on a simple weighted sum of five factors that characterized installations': (1) direct and indirect climate change exposure, (2) likely sensitivity to climate change exposure, (3) regional adaptive capacity, (4) potential vulnerability to listed and at-risk species, and (5) importance to the Army's overall training mission (Table 1). 
Each of these five factors were summarized using one or more standardized subfactors, weighted by a multiplier, and then summed to arrive at an overall index of installation vulnerability. Table 1 lists descriptions of these five factors. The index can be used to assess the relative vulnerability of installations, identify the most important factors affecting vulnerability, identify the conservation partnering and adaptation strategies likely available, and promote coordination and consistency in adaptation planning and management across Army.

Table 1. Factors and subfactors used to assess climate change vulnerability.

\begin{tabular}{|c|c|c|}
\hline Factors & Subfactors & Description \\
\hline \multirow[t]{3}{*}{$\begin{array}{l}\text { 1. Direct and Indirect } \\
\text { Exposure }\end{array}$} & 1.1 Temperature Change & $\begin{array}{l}\text { Mean predicted change in annual temperature by } 2050 \text {, } \\
\text { calculated across installation landscapes }\end{array}$ \\
\hline & 1.2 Moisture Change & $\begin{array}{l}\text { Mean predicted net change in moisture based on the Hamon } \\
\text { AET:PET (actual evapotranspiration potential } \\
\text { evapotranspiration) Moisture Metric, calculated across } \\
\text { installation landscapes }\end{array}$ \\
\hline & 1.3 Sea Level Rise & $\begin{array}{l}\text { Predicted increase in sea level and consequent influence of } \\
\text { storm surges calculated across installation landscapes }\end{array}$ \\
\hline \multirow[t]{2}{*}{ 2. Sensitivity } & 2.1. Historical Thermal Variation & $\begin{array}{l}\text { Mean seasonal temperature variation (difference between the } \\
\text { highest mean monthly maximum temperature and lowest mean } \\
\text { monthly minimum temperature from 1951-2006) calculated } \\
\text { across installation landscapes. Species exposed to low } \\
\text { seasonal temperature variation are expected to be more } \\
\text { vulnerable than species exposed to high seasonal temperature } \\
\text { variation }\end{array}$ \\
\hline & 2.2. Historical Precipitation & $\begin{array}{l}\text { Mean annual precipitation from } 1951-2006 \text { calculated across } \\
\text { installation landscapes. Species in arid climates are expected to } \\
\text { be more vulnerable to reductions in precipitation than species } \\
\text { in mesic climates }\end{array}$ \\
\hline \multirow[t]{2}{*}{ 3. Adaptive Capacity } & 3.1 Anthropogenic Barriers & $\begin{array}{l}\text { Anthropogenically altered landscapes (e.g., urban or agricultural } \\
\text { areas) may hinder the dispersal of species, estimated as } \\
\text { percent developed landcover within a } 50 \mathrm{~km} \text { buffer on } \\
\text { installations }\end{array}$ \\
\hline & 3.2 Protected Lands & $\begin{array}{l}\text { Federal lands offer listed and at-risk species the most } \\
\text { comprehensive protections and represent potential } \\
\text { conservation partners, estimated as percent Federal lands } \\
\text { within a } 50 \mathrm{~km} \text { buffer on installations }\end{array}$ \\
\hline \multirow[t]{2}{*}{$\begin{array}{l}\text { 4. Listed and At-Risk } \\
\text { Species }\end{array}$} & 4.1 Listed and At-risk Species & $\begin{array}{l}\text { Index of the current and potential listed and at-risk species } \\
\text { conservation burden }\end{array}$ \\
\hline & $\begin{array}{l}\text { 4.2 Density of Listed and At-risk } \\
\text { Species }\end{array}$ & The index described in 4.1 divided by installation area \\
\hline 5. Installation Rank & & $\begin{array}{l}\text { ITAM rank reflecting installation importance to the Army's } \\
\text { training and testing missions }\end{array}$ \\
\hline
\end{tabular}




\subsection{Direct and indirect climate change exposure}

Direct exposure of installations and their associated listed and at-risk species to future climate change was evaluated in terms of two subfactors: change in average annual temperature and moisture availability projected for the year 2050 (Table 1). Climate data were sourced from the ClimateWizard team (www.climatewizard.org) and NatureServe (www.natureserve.org/conservation-tools/climate-change-vulnerability-index). Climate and all other spatial data were projected to Alber's Equal Area Conic. Climate data specific to Army installations were extracted from these spatial layers based on installation boundary information sourced from the U.S. Geological Survey (USGS) National Map (http://nationalmap.gov/small_scale/mld/fedlanp.html) and using ArcGIS 10.2.2 (ESRI 2016). A similar process was applied for all other spatially explicit subfactors (Sections 2.3 and 2.4).

The average temperature changes projected across installation assessment areas (Table 1, Subfactor 1.1) ranged from 1.95 to $3.21^{\circ} \mathrm{C}\left(\right.$ mean $\left.=2.67^{\circ} \mathrm{C}\right)$ for J oint Base Lewis-McCord and Camp Dodge J oint Maneuver Training Center, respectively (Appendix A). These values were then rescaled (i.e., standardized). A score range procedure (Eastman et al. 1993, Malczewski 2000) was applied:

$$
x_{i}=\left(R_{i}-R_{\min }\right) /\left(R_{\max }-R_{\min }\right)
$$

where:

$R_{\mathrm{i}}$ represents the observed values

$R_{\min }$ and $R_{\max }$ are the range of observed values

$\mathrm{x}_{\mathrm{i}}$ are the standardized, dimensionless values on a scale of 0 to 1 , with higher values representing greater relevance for climate change vulnerability.

Projected changes in moisture availability (Table 1, Subfactor 1.2) within installation assessment areas were characterized using the Hamon AET:PET moisture metric (Hamon 1961), as prepared by the ClimateWizard team. This metric integrates precipitation and temperature through a ratio of actual evapotranspiration (AET) to potential evapotranspiration (PET), with consideration of total daylight hours and saturated vapor pressure. Average projected changes in Hamon AET:PET moisture metric across installation assessment areas ranged from -0.010 to $-0.120 \%$ (mean 
$=-0.068 \%$ ), for Yuma Proving Ground, AZ and Fort Sill, OK, respectively (Appendix A). Values for this subfactor were standardized with a score range procedure. Resulting values ranged from zero to one, with higher values having greater relevance.

Species and installations may also be impacted by climate change indirectly. Indirect exposure to climate change was assessed via a sea level change subfactor (Table 1, 1.3) that used coastal vulnerability index data acquired from the USGS Coastal Change Hazard Portal (http://marine.usgs.gov/coastalchangehazardsportal). The index ranks relative susceptibility of U.S. coasts to sea level rise within four categories (low, moderate, high, and very high) using information on geomorphology, regional coastal slope, tide range, wave height, relative sea level rise, and shoreline erosion and accretion rates (Thieler and Hammar-Klose 2000). The percentages of the installation assessment areas represented by any of the three highest index categories (i.e., moderate, high, and very high) were estimated within ArcGIS 10.2.2. Only two installations were found to be indirectly impacted by sea level change, with Fort Eustis, VA (14.14\%) more negatively impacted than Aberdeen Proving Ground, MD (5.5\%) (Appendix A). Values for this subfactor were then standardized with a score range procedure. Resulting values ranged from zero to one, with higher values having greater relevance.

\subsection{Climate change sensitivity}

Populations of listed and at-risk species in arid regions are thought to be more vulnerable to projected reductions in precipitation than those residing in mesic regions (e.g., Vale and Brito 2015). Furthermore, populations of listed and at-risk species that have historically experienced little temperature variation may be less able to tolerate projected increases in temperature (Tomanek 2008). Thus, climate change sensitivity has been assessed by evaluating historical precipitation and seasonal temperature variation (e.g., Young et al. 2015). In this effort, sensitivity of installations and their associated listed and at-risk species to future climate change was evaluated in terms of two subfactors: historical precipitation (Table 1, 2.2) and seasonal temperature variation (Table 1, 2.1). Mean annual precipitation and seasonal temperature variation (i.e., difference between the highest mean monthly maximum and lowest mean monthly minimum) from 
1951-2006 were estimated within installation assessment areas using climate data sourced from the Climate Wizard (www.climatewizard.org) and NatureServe (www.natureserve.org/conservation-tools/climate-change-vulnerability-index).

Historical seasonal temperature variation ranged from 15.3 to $43.4^{\circ} \mathrm{C}$ ( mean $=35.2^{\circ} \mathrm{C}$ ) for J oint Base Lewis-McCord, WA and Fort McCoy, WI, respectively (Appendix A). Historical precipitation ranged from 106.5$1469.6 \mathrm{~mm}$ (mean $=846.5 \mathrm{~mm}$ ), for Yuma Proving Ground, AZ and Fort Polk, LA, respectively (Appendix A). The average annual precipitation and seasonal temperature variation calculated across installation assessment areas were then standardized using the score range procedure and then subtracted from one. This transformation caused installations in locations with low historical annual precipitation and temperature variation to have high subfactor scores. Resulting values ranged from zero to one, with higher values having greater relevance.

\subsection{Adaptive capacity}

Adaptive capacity is the ability of a species or system to adapt to changes in climate. Specific information about the evolutionary processes and mechanisms that influence different species' adaptive capacity (e.g., fecundity, mating system, spatial genetic diversity, phenotypic plasticity, etc.) is often not available and is likely hard to synthesize across species. Consequently, in this effort, two subfactors that are likely to affect the adaptive capacity of all species represented on installations were characterized: anthropogenic barriers to dispersal and availability of protected lands that can potentially act as secure stepping stones during range migration.

Anthropogenically altered landscapes (e.g., urban or agricultural areas) reduce and fragment available habitat, which leads to smaller and more isolated populations. They may also hinder the dispersal of species. Dispersal in the face of climate change is important in multiple ways. For example, if climate change causes spatial shifts in vegetation communities, listed and at-risk species that rely on these communities for habitat would need to track this spatial shift, otherwise available habitat would disappear and the species would likely be locally extirpated. Dispersal is also critical in maintaining metapopulation structure. Anthropogenic barriers (Table 1, Subfactor 3.1) to dispersal were characterized by calculating the percentage of 
land within $50 \mathrm{~km}$ buffers of Federal lands represented by developed pasture/ hay and cultivated crop cover types within the 2011 National Land Cover Dataset (Homer et al. 2015). The percent of installation buffers comprised of developed and other intensively used landcover types ranged from 0.2-54.2\% (mean = 20.5\%), for Dugway Proving Ground, UT and Camp Atterbury, IN, respectively (Appendix A). Values for this subfactor were standardized with a score range procedure. Resulting values ranged from zero to one, with higher values having greater relevance.

Protected lands (Table 1, Subfactor 3.2), unlike private lands, are unlikely to be anthropogenically altered in the future due to socio-economic drivers. Protected lands thus provide a coarse metric of the environmental stability of the landbase that species may be able to use for climate change adaptation (e.g., stepping stones of colonization during range shifts), even if their overlap with biodiversity priorities falls short (J enkins et al. 2015), or they are externally impinged upon (Wilson et al. 2014, Martinuzzi et al. 2015).

Of protected lands, Federal landholdings offer listed and at-risk species the most comprehensive protections and also represent potential conservation partners for Army. In this effort, the influence of protected lands on adaptive capacity was estimated as the percentage of Federal lands within a $50 \mathrm{~km}$ buffer on installations. Spatial data for Federal lands were sourced from the USGS National Map. This dataset includes lands owned or administered by the Federal Government, including the Bureau of Land Management, Bureau of Reclamation, Forest Service, DoD, USFWS, National Park Service, Tennessee Valley Authority, and other agencies. The percent of installation buffers comprised of Federal lands ranged from 0.0-99.1\% (mean $=19.1 \%$ ). Several installations have no Federal lands within their buffers (e.g., Combat Training Center [CTC] Fort Custer Training Support [TS], MI; Fort Drum, NY; and Fort Knox, KY), while Camp Navajo, AZ is almost entirely surrounded by Federal lands (Appendix A). Before combining with the anthropogenic barrier subfactor (see Section 2.7), values for this subfactor were standardized with a score range procedure and then subtracted from one. This transformation caused installations with low percentages of Federal lands nearby to have high subfactor scores. Resulting values ranged from zero to one, with higher values having greater relevance. 


\subsection{Listed and at-risk species}

The anticipated increase in restrictions on Army training land use due to climate change-related impacts on listed and at-risk species (Table 1, 4.1) will likely be a function of the number of species occurring on individual installations. A spreadsheet of listed and at-risk species for CONUS Army installations was compiled based on the most recent at-risk (NatureServe 2014) and listed (ACSIM 2010) species summaries (Appendix B). For species that are not Federally listed, or Candidates for listing, only Global Conservation Status Ranked species at risk of G1 (critically imperiled) and G2 (imperiled) were included. Currently listed species impose known impacts to installations, but at-risk species generally impose less of an impact due to fewer restrictions on training land use and greater flexibility of species management.

Despite installation efforts to proactively manage at-risk species, some are ultimately listed. Sperry et al. (2016) developed a logistic regression model of the probability that species proposed for listing under ESA will in fact be listed. Variables included in the model were the species taxonomic group and the percentage of the species' range lost to intensive human land use (e.g., urbanized or agricultural). This work used the former to weight at-risk species on installations by multiplying the number of species in each taxonomic group by the probabilities listed in Table 2 . For atrisk species, an additional weighting, in which the value obtained in the former step was multiplied by 0.25 , was applied. This was done to approximate the uncertainty in future listing of at-risk species that have not yet been petitioned for listing under the ESA. The derived numbers for each taxonomic group were then summed and added to the number of listed species on each installation. For example, Fort Hunter Liggett has six listed species and 21 at-risk plant species, which results in a value of 9.3 (6 $+[21 * 0.63 * 0.25])$. Resulting values ranged from 0.00 to 16.63 (mean $=$ 3.92). Two installations (e.g., Camp J oseph T. Robinson, AK, and Fort William Henry Harrison, MT) had no listed or at-risk species, while J oint Base Lewis-McCord, WA had the most (Appendix A).

Because the magnitude of the impact that listed and at-risk species are likely to have on installations is also expected to vary as a function of available training area, these values were divided by installation area $\left(\mathrm{km}^{2}\right)$ to generate a density-based index of listed and at-risk species for each installation 
(Table 1, Subfactor 4.2). Resulting values ranged from 0.00 to 0.36 species $/ \mathrm{km}^{2}$ (mean $=0.25$ ) (Appendix A). The values estimated for both subfactors were standardized with the score range procedure before being combined in the overall index of installation vulnerability (see Section 2.7).

Table 2. Probability of Federal listing by taxonomic group used to weight species at-risk. Numbers in parentheses represent number of species used to develop the model.

\begin{tabular}{|l|c|}
\hline Taxonomic Group & Probability Listing \\
\hline Arthropod (24) & 0.29 \\
\hline Birds (18) & 0.72 \\
\hline Fish (14) & 0.64 \\
\hline Mammal (20) & 0.65 \\
\hline Plants (35) & 0.63 \\
\hline Reptile (10) & 0.60 \\
\hline \multicolumn{2}{|l|}{ Source: Sperry et al. (2016). } \\
\hline
\end{tabular}

\subsection{Installation ranks}

This factor used the rankings of installations calculated by the Army ITAM Program in 2009. ITAM rankings were calculated based on a variety of factors including training throughput, installation acreage, and soil properties. Of the variables included in the rankings, throughput was more heavily weighted (twice that of other factors). Ranks vary from 1 to 6 , with lower values indicating higher relevance for the Army's training and testing missions (Appendix A). The ITAM ranks were transformed using the score range procedure and then subtracted from one. Resulting values ranged from zero to one and had a positive relationship with importance.

\subsection{Calculating climate change vulnerability scores for installations}

To identify the relative risk that installations are potentially exposed to as a consequence of emerging climate change impacts, the standardized values of the two subfactors under each of the five factors were added (except installation rank, which does not have any subfactors), multiplied by a weight (Table 3) characterizing relative importance, and then summed for each installation (Kirkwood 1997). Note that equal weights (0.15), indicating equal importance, were assigned to all factors except the listed and atrisk species factor, which was assigned a larger weight (0.40) because of its specific emphasis within this vulnerability assessment. 
The standardizing transformations applied to the various subfactors described in previous sections ensured that climate change vulnerability was not unduly influenced by the disparate values of the different subfactors. Installation climate change vulnerability scores generated by this process should be interpreted in a relative, rather than an absolute context. Climate change vulnerability was also estimated for installations without including the installation rank factor as it likely encompasses many variables considered by the BRAC process and this redundancy may not be desirable when this is the intended use. Appendix $\mathrm{C}$ presents these scores.

Table 3. Weights multiplied by the five factors to calculate climate change vulnerabilities of Army ITAM installations.

\begin{tabular}{|l|c|}
\hline Factor & Weighting \\
\hline Exposure & 0.15 \\
\hline Sensitivity & 0.15 \\
\hline Adaptive capacity & 0.15 \\
\hline Listed and at-risk species & 0.40 \\
\hline Installation rank & 0.15 \\
\hline
\end{tabular}

\subsection{Examining differences in installation climate change vulnerability factors and scores across USFWS regions}

Many listed and at-risk species can have surprisingly large geographic ranges (e.g., the Indiana bat), and consequently occur on multiple Army installations. In this case, there are potential benefits to developing and coordinating climate change management initiatives at a regional scale instead of on an installation-by-installation basis. For example, the magnitude of climate change exposure on one installation may cast doubt on the long-term viability of a local population of a given species, while exposure might be minimal on other installations within its range. Given this scenario, it is possible that cross-installation, conservation banking strategies would be welcomed by the USFWS. This type of strategy would likely require significant coordination with multiple USFWS Ecological Services Field Offices and their regional office(s).

Regional differences in the factors that affect climate change vulnerability are also anticipated due to spatial variation in biogeography, elevation, land-use patterns, etc. Thus across regions, installations and their associated listed and at-risk species will be subject to varying climate change vul- 
nerabilities. To identify emerging regional challenges and potential opportunities, mean scores for each of the five factors and overall climate change vulnerability were compared for installations within the eight USFWS regions (Table 4).

Table 4. USFWS regions and associated states.

\begin{tabular}{|l|l|}
\hline Region & States \\
\hline 1 Pacific & $\begin{array}{l}\text { Hawaii, Idaho, Oregon, Washington, American Samoa, Commonwealth of the Northern Mariana } \\
\text { Islands, Guam and the Pacific Trust Territories }\end{array}$ \\
\hline 2 Southwest & Arizona, New Mexico, Oklahoma, and Texas \\
\hline 3 Midwest & Illinois, Indiana, lowa, Ohio, Michigan, Minnesota, Missouri, and Wisconsin \\
\hline 4 Southeast & $\begin{array}{l}\text { Alabama, Arkansas, Florida, Georgia, Kentucky, Louisiana, Mississippi, North Carolina, South } \\
\text { Carolina, Tennessee, Puerto Rico, and the U.S. Virgin Islands }\end{array}$ \\
\hline 5 Northeast & $\begin{array}{l}\text { Connecticut, Delaware, District of Columbia, Maine, Maryland, Massachusetts, New Hampshire, New } \\
\text { Jersey, New York, Pennsylvania, Rhode Island, Vermont, Virginia, and West Virginia }\end{array}$ \\
\hline 6 Mountain-Prairie & Colorado, Kansas, Montana, Nebraska, North Dakota, South Dakota, Utah, and Wyoming \\
\hline 8 Pacific Southwest & California, Nevada \\
\hline
\end{tabular}




\section{Results and Discussion}

\subsection{Direct and indirect exposure}

The five installations with the highest values for the factor characterizing direct and indirect climate change exposure, ordered high-to-low were Fort Sill, OK, Fort Eustis, VA, Fort Carson, CO, Camp Williams, UT, and Camp Dodge, IA (Table 5). Military Training Center-Heavy (MTC-H) Camp Roberts, CA and Fort Hunter Liggett, CA had the lowest estimated scores for this factor. Many coastal portions of the country are projected to experience smaller changes in temperatures and precipitation than the interior United States, due to buffering effects of the oceans. Land tends to cool and heat more rapidly than water, such that areas away from large bodies of water experience greater seasonal extremes of temperature than do coastal communities. Proximity to large bodies of water also tends to positively influence precipitation levels; coastal locations receive generally higher amounts than interior areas primarily due to higher levels of evaporation. Also, the indirect impacts of sea level rise are projected to be greater along the Atlantic and Gulf coasts, than along the Pacific coast (Krasting et al. 2016).

Table 5. Weighted scores for five factors used to estimate climate change vulnerability of 43 CONUS Army ITAM installations. Installations are ordered high-to-low based on vulnerability.

\begin{tabular}{|l|l|l|l|l|l|l|c|}
\hline & State & Exposure* $^{*}$ & Sensitivity & $\begin{array}{l}\text { Adaptive } \\
\text { Capacity }\end{array}$ & Species & $\begin{array}{l}\text { Installation } \\
\text { Rank }\end{array}$ & Vulnerability \\
\hline Parks Reserve Forces Training Area & CA & 0.106 & 0.235 & 0.229 & 0.476 & 0.090 & 1.137 \\
\hline Joint Base Lewis-McCord & WA & 0.108 & 0.181 & 0.211 & 0.454 & 0.150 & 1.103 \\
\hline Fort Huachuca & AZ & 0.170 & 0.198 & 0.094 & 0.473 & 0.030 & 0.965 \\
\hline Fort Bliss & TX & 0.162 & 0.187 & 0.091 & 0.311 & 0.150 & 0.901 \\
\hline Fort Carson & CO & 0.264 & 0.144 & 0.137 & 0.142 & 0.150 & 0.838 \\
\hline Camp Atterbury & IN & 0.229 & 0.096 & 0.293 & 0.113 & 0.090 & 0.820 \\
\hline Yakima Training Center & WA & 0.090 & 0.203 & 0.219 & 0.126 & 0.150 & 0.788 \\
\hline Fort Hood & TX & 0.211 & 0.147 & 0.190 & 0.086 & 0.150 & 0.784 \\
\hline Fort Bragg & NC & 0.109 & 0.113 & 0.232 & 0.209 & 0.120 & 0.783 \\
\hline MTC-H Camp Roberts & CA & 0.063 & 0.202 & 0.194 & 0.260 & 0.060 & 0.780 \\
\hline Fort Riley & KS & 0.222 & 0.087 & 0.232 & 0.115 & 0.120 & 0.776 \\
\hline Fort Campbell & KY & 0.214 & 0.085 & 0.267 & 0.072 & 0.120 & 0.757 \\
\hline Fort Sill & OK & 0.272 & 0.116 & 0.240 & 0.033 & 0.090 & 0.750 \\
\hline Fort Benning & GA & 0.124 & 0.117 & 0.188 & 0.197 & 0.120 & 0.746 \\
\hline Fort Stewart & GA & 0.104 & 0.134 & 0.195 & 0.186 & 0.120 & 0.739 \\
\hline
\end{tabular}

* Blue $=$ minimum , white $=$ median $\left(50^{\text {th }}\right.$ percentile $)$, red $=$ maximum , and transitional colors represent intermediate percentiles. 


\begin{tabular}{|c|c|c|c|c|c|c|c|}
\hline Installation & State & Exposure & Sensitivity & $\begin{array}{l}\text { Adaptive } \\
\text { Capacity }\end{array}$ & Species & $\begin{array}{l}\text { Installation } \\
\text { Rank }\end{array}$ & Vulnerability \\
\hline Camp Bullis & $\mathrm{TX}$ & 0.176 & 0.163 & 0.267 & 0.036 & 0.090 & 0.733 \\
\hline Fort Eustis & VA & 0.265 & 0.126 & 0.211 & 0.057 & 0.030 & 0.689 \\
\hline Fort Hunter Liggett & $\mathrm{CA}$ & 0.053 & 0.174 & 0.111 & 0.255 & 0.090 & 0.684 \\
\hline Fort Gordon & GA & 0.108 & 0.120 & 0.199 & 0.194 & 0.060 & 0.680 \\
\hline Fort Knox & KY & 0.217 & 0.093 & 0.215 & 0.063 & 0.090 & 0.678 \\
\hline Fort Rucker & $\mathrm{AL}$ & 0.134 & 0.117 & 0.213 & 0.109 & 0.090 & 0.663 \\
\hline Fort McCoy & WI & 0.197 & 0.070 & 0.241 & 0.060 & 0.090 & 0.657 \\
\hline White Sands Military Range & NM & 0.171 & 0.173 & 0.051 & 0.257 & 0.000 & 0.653 \\
\hline CTC Fort Custer TS & $\mathrm{MI}$ & 0.207 & 0.108 & 0.280 & 0.050 & 0.000 & 0.646 \\
\hline Aberdeen Proving Ground & $\mathrm{MD}$ & 0.204 & 0.106 & 0.237 & 0.090 & 0.000 & 0.637 \\
\hline $\begin{array}{l}\text { Camp Dodge Joint Maneuver Training } \\
\text { Center }\end{array}$ & IA & 0.237 & 0.087 & 0.269 & 0.010 & 0.030 & 0.633 \\
\hline $\begin{array}{l}\text { Military Training Area-Light (MTA-L) } \\
\text { Camp Williams }\end{array}$ & UT & 0.254 & 0.162 & 0.119 & 0.015 & 0.060 & 0.610 \\
\hline Fort Drum & NY & 0.166 & 0.076 & 0.175 & 0.056 & 0.120 & 0.592 \\
\hline Fort Leonard Wood & MO & 0.227 & 0.085 & 0.088 & 0.102 & 0.090 & 0.592 \\
\hline Camp Joseph T Robinson & AR & 0.195 & 0.094 & 0.239 & 0.000 & 0.060 & 0.588 \\
\hline Fort Polk & LA & 0.185 & 0.101 & 0.141 & 0.038 & 0.120 & 0.585 \\
\hline $\begin{array}{l}\text { Fort Chaffee Military Training Center } \\
\text { (MTC) }\end{array}$ & AR & 0.212 & 0.087 & 0.152 & 0.035 & 0.090 & 0.576 \\
\hline Fort Dix & NJ & 0.129 & 0.093 & 0.252 & 0.009 & 0.090 & 0.572 \\
\hline MTC-H Camp Grayling & $\mathrm{MI}$ & 0.184 & 0.101 & 0.153 & 0.072 & 0.060 & 0.571 \\
\hline Fort Jackson & SC & 0.117 & 0.122 & 0.220 & 0.050 & 0.060 & 0.570 \\
\hline Fort Pickett, ARNG MTC & VA & 0.131 & 0.102 & 0.165 & 0.079 & 0.090 & 0.567 \\
\hline Fort A P Hill & VA & 0.138 & 0.108 & 0.193 & 0.034 & 0.090 & 0.563 \\
\hline $\begin{array}{l}\text { Military Training Area (MTA) Fort Wm } \\
\text { Henry Harrison }\end{array}$ & MT & 0.216 & 0.164 & 0.122 & 0.000 & 0.060 & 0.561 \\
\hline Fort Irwin & $\mathrm{CA}$ & 0.102 & 0.195 & 0.015 & 0.065 & 0.120 & 0.498 \\
\hline Fort Lee & VA & 0.120 & 0.108 & 0.189 & 0.079 & 0.000 & 0.496 \\
\hline Yuma Proving Ground & $A Z$ & 0.089 & 0.207 & 0.089 & 0.077 & 0.000 & 0.463 \\
\hline Camp Navajo & $A Z$ & 0.228 & 0.139 & 0.001 & 0.043 & 0.030 & 0.440 \\
\hline Dugway Proving Ground & UT & 0.199 & 0.143 & 0.016 & 0.077 & 0.000 & 0.435 \\
\hline
\end{tabular}

$*$ Blue $=$ minimum, white $=$ median $\left(50^{\text {th }}\right.$ percentile $)$, red $=$ maximum, and transitional colors represent intermediate percentiles.

Differences in direct and indirect climate change exposure were identified across USFWS regions. Region 6 (Mountain-Prairie) had the largest mean exposure score, which was significantly higher than mean scores in Regions 1(Pacific), 8 (Pacific Southwest) and 4 (Southeast). Mean exposure scores for Regions 2 (Southwest) and 3 (Midwest) were also notably high, being significantly higher than one, or more of the other seven regions (Table 6). 
Table 6. Mean scores and ranges (in parentheses) for five climate change factors and the overall vulnerability of 43 CONUS Army ITAM installations within seven USFWS regions. Means designated by the same letter within columns do not differ at $P=0.05$ by Tukey's Honestly

Significant Difference in an across-region comparison.

\begin{tabular}{|c|c|c|c|c|c|c|c|}
\hline $\begin{array}{l}\text { USFWS } \\
\text { Region }\end{array}$ & Count & Exposure & Sensitivity & $\begin{array}{l}\text { Adaptive } \\
\text { Capacity }\end{array}$ & Species & Installation & Vulnerability \\
\hline 1 & 2 & $\begin{array}{c}0.099 \\
(0.090-0.108) \\
a b\end{array}$ & $\begin{array}{c}0.192 \\
(0.181-0.203) \\
a\end{array}$ & $\begin{array}{c}0.215 \\
(0.211-0.219) \\
a\end{array}$ & $\begin{array}{c}0.289 \\
(0.125-0.454) \\
a\end{array}$ & $\begin{array}{c}0.150 \\
(0.150-0.150) \\
a\end{array}$ & $\begin{array}{c}0.946 \\
(0.788-1.103) \\
a\end{array}$ \\
\hline 2 & 8 & $\begin{array}{c}0.185 \\
(0.089-0.272) \\
c\end{array}$ & $\begin{array}{c}0.166 \\
(0.116-0.207) \\
b\end{array}$ & $\begin{array}{c}0.128 \\
(0.001-0.267) \\
a\end{array}$ & $\begin{array}{c}0.164 \\
(0.036-0.473) \\
a\end{array}$ & $\begin{array}{c}0.068 \\
(0.000-0.150) \\
a\end{array}$ & $\begin{array}{c}0.711 \\
(0.440-0.965) \\
a\end{array}$ \\
\hline 3 & 6 & $\begin{array}{c}0.214 \\
(0.184-0.237) \\
\text { ad }\end{array}$ & $\begin{array}{c}0.091 \\
(0.069-0.108) \\
a b c\end{array}$ & $\begin{array}{c}0.221 \\
(0.088-0.293) \\
a\end{array}$ & $\begin{array}{c}0.068 \\
(0.010-0.113) \\
a\end{array}$ & $\begin{array}{c}0.060 \\
(0.000-0.090) \\
a\end{array}$ & $\begin{array}{c}0.653 \\
(0.571-0.820) \\
a\end{array}$ \\
\hline 4 & 11 & $\begin{array}{c}0.156 \\
(0.104-0.217) \\
e\end{array}$ & $\begin{array}{c}0.107 \\
(0.085-0.122) \\
\text { abd }\end{array}$ & $\begin{array}{c}0.205 \\
(0.141-0.267) \\
a\end{array}$ & $\begin{array}{c}0.105 \\
(0.000-0.201) \\
a\end{array}$ & $\begin{array}{c}0.095 \\
(0.060-0.120) \\
a\end{array}$ & $\begin{array}{c}0.669 \\
(0.569-0.783) \\
a\end{array}$ \\
\hline 5 & 7 & $\begin{array}{c}0.165 \\
(0.119-0.265) \\
f\end{array}$ & $\begin{array}{c}0.103 \\
(0.076-0.126) \\
\text { Abe }\end{array}$ & $\begin{array}{c}0.203 \\
(0.165-0.237) \\
a\end{array}$ & $\begin{array}{c}0.056 \\
(0.009-0.090) \\
a\end{array}$ & $\begin{array}{c}0.060 \\
(0.000-0.120) \\
a\end{array}$ & $\begin{array}{c}0.588 \\
(0.496-0.689) \\
a\end{array}$ \\
\hline 6 & 5 & $\begin{array}{c}0.231 \\
(0.198-0.264) \\
\text { beg }\end{array}$ & $\begin{array}{c}0.140 \\
(0.087-0.162) \\
\text { cf }\end{array}$ & $\begin{array}{c}0.125 \\
(0.016-0.231) \\
a\end{array}$ & $\begin{array}{c}0.069 \\
(0.000-0.142) \\
a\end{array}$ & $\begin{array}{c}0.078 \\
(0.000-0.150) \\
a\end{array}$ & $\begin{array}{c}0.644 \\
(0.435-0.838) \\
a\end{array}$ \\
\hline 8 & 4 & $\begin{array}{c}0.081 \\
(0.053-0.106) \\
\text { cdg }\end{array}$ & $\begin{array}{c}0.202 \\
(0.174-0.235) \\
\text { cdef }\end{array}$ & $\begin{array}{c}0.137 \\
(0.015-0.229) \\
a\end{array}$ & $\begin{array}{c}0.264 \\
(0.065-0.476) \\
a\end{array}$ & $\begin{array}{c}0.090 \\
(0.060-0.090) \\
a\end{array}$ & $\begin{array}{c}0.775 \\
(0.498-1.137) \\
a\end{array}$ \\
\hline
\end{tabular}

The variability in climate change exposure identified across installations and regions suggests different mitigation strategies will likely be needed. First, installations with relatively high exposure but lower scores for sensitivity and adaptive capacity (e.g., Fort Leonard Wood, MO and Fort Chaffee MTC, AR) can attempt to reduce the local consequences of climate change on the specific habitat needs of affected species when feasible (Table 5, Figure 1, Class 1). For example, water could be added to breeding ponds of atrisk amphibian species to extend the hydroperiod, facilitating successful metamorphosis and juvenile dispersal. Installations and species that are likely to be exposed to climate change, but that do not suffer from high sensitivity or limited adaptive capacity, have somewhat optimistic prospects for near-term local population persistence and/ or climate change adaptation. If feasible, efforts should focus on reducing climate change exposure and maintaining low sensitivity and adaptive capacity scores. 
Figure 1. Conceptual diagram of combinations of climate change exposure, sensitivity, and adaptive capacity that identify seven classes of vulnerability having different implications for prioritization and strategic planning.

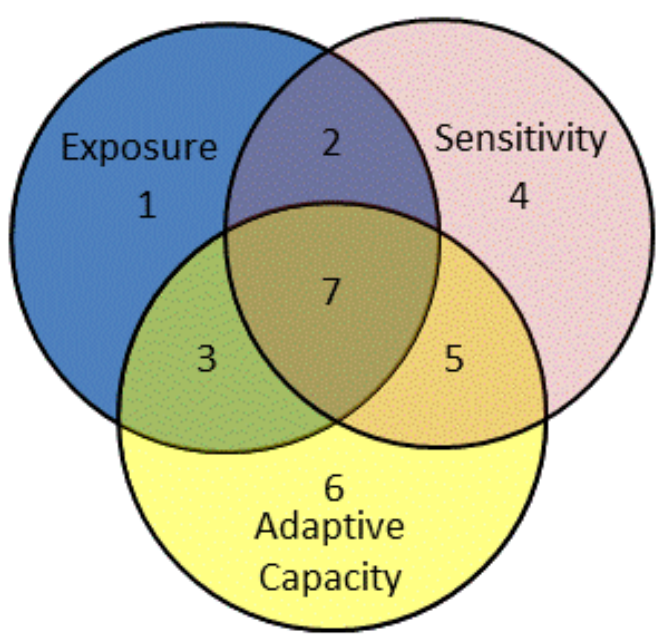

These seven classes include: 1 . potentially vulnerable due to high exposure, but vulnerability is presumably tempered by low sensitivity and adaptive capacity, 2. potential adapters having high exposure and sensitivity, but low adaptive capacity scores, 3. potential persisters having high exposure and adaptive capacity scores but low sensitivity, 4. low latent risk due to high sensitivity, but low exposure and adaptive capacity, 5 . high latent risk due to high sensitivity and adaptive capacity scores, but low exposure, 6 . low latent risk due to a high adaptive capacity score, but low exposure and sensitivity, and 7. highly vulnerable due to high exposure, sensitivity and adaptive capacity. After Foden et al. 2013, doi:10.1371/journal.pone.0065427.g001

Second, installations and species subjected to relatively high climate change exposure and sensitivity, but low adaptive capacity scores, can be classified as potential adapters (see Foden et al. 2013, Figure 1, Class 2). These results suggest that Fort Carson, CO, MTA-L Camp Williams, MTA, UT, Fort William Henry Harrison, MT, and Camp Navajo, AZ, and possibly Dugway Proving Ground, UT, will likely face this combination of factors (Table 5). In this situation, efforts should focus on reducing exposure and sensitivity, while maintaining adaptive capacity. Although this approach used historical climate variables as a means of characterizing sensitivity for multiple species on installations, the mitigation efforts used by installations to either reduce or maintain this factor will need to target the sensitivity of specific species. For example, climate change-related increases in species' sensitivity to the impacts of certain invasive species could be mitigated by implementing control efforts that specifically target this source of sensitivity (Abatzoglou and Kolden 2011). 
Third, where exposure and adaptive capacity scores are high, but sensitivity is low, one would anticipate some potential for species persistence (Figure 1, Class 3; Foden et al. 2013). These results suggest approximately eight of the study installations will likely face this combination of factors, including: Camp Atterbury, IN; Fort Riley, KS; Fort Campbell, KY; Fort Knox, KY; Fort McCoy, WI; CTC Fort Custer, MI; Aberdeen Proving Ground, MD; and Camp Dodge J oint Maneuver Training Center, IA (Table 4). In this situation, efforts should focus on reducing the impacts of climate change exposure and constraints on adaptive capacity, while maintaining low sensitivity.

Fourth, installations and species subjected to relatively high climate change exposure, sensitivity, and adaptive capacity scores will likely be the most vulnerable. Only Fort Eustis, VA was found to have relatively high scores for these three factors (Table 5; Figure 1, Class 7). To minimize the loss of unrestricted access to training land use on installations due to the additive effects of climate change and listed and at-risk species, efforts should target: (1) the conservation of any existing at-risk species to help eliminate the need for listing, and (2) negotiations with the USFWS to evaluate the merits and feasibility of conserving populations of listed species on the installation.

Fifth, installations and species subjected to lower climate change exposure, sensitivity, and adaptive capacity scores are less likely to be vulnerable in contrast with other installations. Fort Pickett, VA, and to a lesser degree Fort A.P. Hill, VA, were found to havelower scores for all three factors (Table 5). One might anticipate some potential for species persistence under this scenario.

It is worth noting that this work used climate projections made available by the ClimateWizard team and NatureServe, however the approach can readily use other sources of climate change data as they may become available. It is also important to remember that the adopted approach characterized climate change as relative change, but no explicit interpretation of the magnitude of change was made. Consequently, it is possible that high relative exposure may in fact represent a projected change in climate that does not warrant great concern. That being said, Army installations from across the Continental United States were included to ensure that some of the greatest and smallest changes in climate anticipated for the country would be represented in the analysis, and would therefore be likely to reflect actionable val- 
ues. Still, there is also potentially great benefit in conducting species-specific climate change vulnerability analyses at multiple scales before finalizing and targeting mitigation actions (e.g., Hohmann and Wall 2016).

\subsection{Sensitivity}

The sensitivity factor ranged from 0.070 to 0.235 for Fort MoCoy, WI and Parks Reserve Forces Training Area, CA, respectively (Table 5). Regions that receive higher amounts of precipitation are anticipated to beless affected by projected changes in precipitation than are regions that receive little precipitation. Likewise, regions with high seasonal temperature variation are expected to be less impacted by temperature changes than regions with less seasonal temperature variation. Consequently, many of the installations with the highest sensitivity scores are from arid regions, such as the Southwest, while the lowest sensitivity scores are from mesic, continental interior regions.

Differences in mean sensitivity scores were identified across USFWS regions, with Army installations in Regions 1(Pacific), 2 (Southwest), and 8 (Pacific Southwest) having higher sensitivity scores than installations in Regions 3 (Great Lakes-Big Rivers), 4 (Southeast), and 5 (Northeast). Additionally, sensitivity scores were higher in Region 8 than Region 6 (Mountain-Prairie) and higher in Region 6 than Region 3 (Table 6). The variability in climate change sensitivity identified across installations and regions suggests different mitigation strategies will likely be needed.

First, installations and species that are likely to be sensitive to climate change, but that are not likely to suffer from high exposure or limited adaptive capacity have optimistic prospects for near-term local population persistence and/ or climate change adaptation. Installations fitting this classification, include Fort Huachuca, CA, Fort Bliss, TX, Fort Hunter Liggett, CA, Fort Irwin, CA, and Yuma Proving Ground, AZ. These installations would benefit from efforts to maintain lower levels of exposure and lessen constraints on adaptive capacity (Table 5, Figure 1, Class 4). They can also attempt to reduce the local consequences of high sensitivity for affected species when feasible. As suggested above, efforts to reduce sensitivity should focus on actionable reduction of climate change-related sensitivity such as invasive species (Hellman et al. 2008), predation risk (e.g., Cox et al. 2013), or temperature dependent sex determination (J anzen 
1994). Efforts could also focus on maintaining low climate change exposure and adaptive capacity scores.

Second, installations and species having relatively high sensitivity and adaptive capacity scores, but low climate change exposure can be classified as having high latent risk (Foden et al. 2013; Figure 1, Class 5). These installations pose a potential future risk should climate change projections be underestimated, or for time periods beyond 2050. These results suggest that Parks Reserve Forces Training Area, CA; J oint Base Lewis-McCord, WA; and Yakima Training Center, WA have high latent risk (Table 5). In this situation, efforts should focus on reducing exposure and sensitivity, while maintaining adaptive capacity.

The consequences of sensitivity are undoubtedly tied to the magnitude and timing of climate change exposure and will vary among species. Speciescentric climate change vulnerability assessments typically include many additional considerations that focus on habitat microsite, physiology, diet, inter-specific interactions, phenology, etc. (e.g., Young et al. 2015), as well as other measures of exposure, such as habitat change and climate velocity (Loarie et al. 2009, Dichinson et al. 2014). This effort only examined historical precipitation and seasonal temperature variation. Consequently, there is potentially great benefit in conducting species-specific climate change vulnerability analyses at multiple scales before finalizing and targeting mitigation actions (e.g., Hohmann and Wall 2016).

\subsection{Adaptive capacity}

The adaptive capacity factor ranged from 0.001 to 0.293 for Camp Navajo, AZ and Camp Atterbury, IN, respectively (Table 5). Camp Navajo, AZ, like many other installations with low adaptive capacity scores, is located in the western United States, where there are large tracts of Federal lands and much of the landscape has not been transformed by development. In contrast, Camp Atterbury, IN, which had a higher score, is located in the Midwest, where much of the landscape is under intensive agricultural use and comparatively little area is under Federal stewardship.

No differences in adaptive capacity scores were identified across USFWS regions (Table 6). This was somewhat surprising given that the percent of developed landcover was expected to be higher and the percent of Federal 
lands was expected to be lower in the eastern United States compared to the western United States. It could be that local encroachment on installations in the western United States has increased to a greater degree than on eastern installations, and that this has offset any potential regional differences in overall adaptive capacity.

The variability in adaptive capacity identified across installations suggests that different mitigation strategies will likely be needed. Installations and species that are likely to experience constraints on adaptive capacity (Figure 1, Class 6), but that will not suffer from high exposure or sensitivity, have multiple options for mitigating climate change impacts. High adaptive capacity scores suggest constraints on species dispersal and conservation partnering opportunities with other Federal landowners. Although other Federal land managers are preferred partners, the conservation achievements that can be accomplished by partnering with state and private landowners should not be discounted (e.g., Candidate Conservation Agreement, Safe Harbor Agreement). Installations having high adaptive capacity scores, can promote regional conservation with private partners via the DoD Readiness and Environmental Protection Integration (REPI) and Army Compatible Use Buffer (ACUB) programs, which have contributed greatly to military readiness and the environmental protection (Messer et al. 2016). Of the targeted installations, only Fort Dix, NJ fit this classification (Table 5).

This approach to estimating constraints on species and installation adaptive capacity used the percentage of land managed by Federal agencies and the percentage eliminated as potential habitat by urban development and other intensive human land uses within a $50 \mathrm{~km}$ buffer of installation boundaries. Although this approach is appropriate for screening a large number of species on multiple installations, its suitability for evaluating the adaptive capacity of any individual species is uncertain. For example, species endemic to a small geographic range, dependent on highly localized and rare edaphic conditions, and having limited dispersal ability (e.g., many cave and plant species) would not be expected to shift their range under climate change even if much of the landscape was undeveloped. Species have unique habitat needs and dispersal abilities; consequently, strategies used by installations to improve adaptive capacity should strive to meet the specific needs of target species. An example of a more speciescentric approach would be to specifically evaluate the availability and connectedness of habitats used by focal species (e.g., McRae and Shah 2009). 
Additionally, there are likely benefits to adopting a dynamic as opposed to a static assessment of regional land use. It is anticipated that the land use within the landscapes surrounding installations will change over time due to urbanization as well as climate (Ordonez et al. 2014). The location and magnitude of these changes will vary based on shifts in the population, zoning regulations, resource availability, land form constraints, etc. Detailed installation-specific assessments will likely want to incorporate projections of future population densities and land use change. Several methods that are available include the ERDC-CERL-maintained Regional Urban Growth model (RUG) (Westervelt et al. 2011), the Land-use Evolution and Impact Assessment Model (LEAM) (Deal and Pallathucheril 2009), and the U.S. Environmental Protection Agency's (USEPA's) Integrated Climate and Land Use Scenarios (ICLUS) model (Bierwagen and Morefield 2014).

\subsection{Listed and at-risk species}

The scores for the listed and at-risk species factor ranged from 0.000 to 0.476 (Table 5). Neither MTA Fort William Henry Harrison, MT, nor CampJ oseph T Robinson, AR, are known to have any listed or at-risk species and consequently had a score of zero. The installation having the highest score for this factor was Parks Reserve Forces Training Area, CA, which has a high density of listed and at-risk species. Other installations with notably high scores for this factor included Fort Huachuca, CA, and J oint Base Lewis-McCord, WA.

No differences in mean listed and at-risk species scores were identified across USFWS regions (Table 6). Region 5 (Northeast) had the lowest (0.058) and Region 1 (Pacific) had the highest (0.289) mean scores for the listed and at-risk species factor. Fortuitously, the latter region also had one of the lowest climate change exposure scores (Table 6).

This assessment used information about the number and density of listed and at-risk species found on installations based on a 2010 summary of listed species and a more recently completed summary of at-risk species. However this approach is potentially limiting in a number of ways.

First, the listed and at-risk species represented on installations is ever changing due to listing decisions, down listing, species surveys, and changes in the conservation status of species. This is particularly true at 
the present time due to the large number of listing petitions that the USFWS is actively reviewing. Sperry et al. (2016) estimated that as many as 230 species under active review potentially occur on Army installations.

Second, the number and density of species may or may not directly translate into training restrictions, which are instead influenced by the number and size of populations, as well at their overlap and compatibility with training land use. One could explicitly evaluate this overlap where data are available, or one could employ species distribution modeling to better characterize potential overlap. Consequently, it would be appropriate to consider the scores presented for this factor as dynamic estimates. Also, local scale assessments are likely necessary to inform installation management decisions.

\subsection{Installation ranks}

Scores for the installation rank factor represent a simple transformation of ITAM rankings and thus provide no novel information when examined separately. Since mean installation rank scores did not differ among USFWS regions (Table 6), no additional discussion of this factor is presented here. However, it is worth mentioning that, from a BRAC perspective, a comparison of the vulnerability score to the ITAM rankings could provide a way to define high value installations that are low risk versus high/ high, low/low, or low/ high (Value/ ITAM). In BRAC, the low vulnerability/ high ITAM installation would be considered of greatest value. Appendix C provides vulnerability scores calculated without installation ranks.

\subsection{Threatened and endangered species related climate change vulnerabilities of installations}

Previous sections summarized the scores of each of the five factors used to estimate installation climate change vulnerabilities. This section summarizes results for the aggregate climate change vulnerability scores estimated after applying weights to the factors and summing for each installation (see Section 2.7). The ranking of installations and their relative values are potentially useful for: (1) identifying the most vulnerable installations, (2) planning additional funding needs beyond those that might already be identified for installations based on currently listed and at-risk species, (3) prioritizing limited funds available for abatement, or (4) informing the BRAC process. 
Installation climate change vulnerability scores ranged from 0.435 to 1.137 for Dugway Proving Ground, UT and Parks Reserve Forces Training Area, CA, respectively (Table 5). The latter installation had a relatively low climate change exposure score, but intermediate to high scores for the remaining four factors. In contrast, Dugway Proving Ground, UT had low scores for adaptive capacity and installation rank factors, but intermediate exposure and sensitivity scores. Fortuitously, nearly all installations with high vulnerability scores (i.e., $>0.765$, upper quartile) have relatively low scores for one or more of the five component factors, which suggests that mitigation options are likely available. Fort Hood, TX may present the greatest management challenge in the face of climate change, given that the listed species factor and all the explicitly climate change-related factors had intermediate to high scores (Table 5).

Comparisons across USFWS regions did not identify any differences in mean installation climate change vulnerability scores. Still, the differences identified for individual factors (i.e., exposure and sensitivity) may provide insight about the potential need for and advantages of using regional mitigation approaches (see Sections 3.1-3.4). Wilhoit et al. (2016) evaluated seven regionally representative Army installations for vulnerability to climate change based on a simple approach that was comparable to the listed and at-risk species factor calculated in this effort. However, their approach did not include any specific information about climate change vulnerability. Interestingly, the five CONUS installations evaluated by both efforts were ranked similarly, except for Fort Bliss, TX, which was given a much higher ranking when additional climate change variables were considered.

Sperry et al. (2016) also conducted an Army-wide assessment of the potential emerging risk to installations associated with listed and at-risk species. Since their approach did not consider the consequences of climate change on potential future impacts, it is interesting to examine the potential additional effect of climate change vulnerability identified by this approach. Five of the installations included in this effort were among the top 20 installations they determined most likely to be impacted. Considering their ranking of installations relative to that shown in Table 5, it is apparent that climate change vulnerability has the potential to increase impacts on Army training beyond that suggested by Sperry et al. (2016). It may also offer some reassurance to Army managers to know that climate change vulnerability is not likely to exacerbate impacts to all installations. 


\section{Conclusions and Recommendations}

\subsection{Conclusions}

Mandates for DoD and the Army to address climate change are in place, but specific approaches that might be adopted to address assessment, monitoring, and adaptation strategies are still evolving. Although vulnerability assessments are an important first step in ensuring future conservation successes for listed and at-risk species, this information is not widely available to regional or Headquarters decision makers. This effort developed and demonstrated a relatively simple method for generating climate change vulnerability assessments for installations using factors that characterized the number of listed and at-risk species, climate change exposure, sensitivity, adaptive capacity and installation importance. The approach is appealing in that it: (1) transparently retains the information about the five factors used in ranking, (2) satisfies the need for consistent assessment methods that can be conducted with broadly available data and that allow meaningful comparisons, and (3) complements recent Army-wide, installation-focused evaluations of proposed species' potential impacts on training (Sperry et al. 2016).

\subsection{Recommendations}

The approach to vulnerability assessment demonstrated here is suitable as a first pass assessment for evaluating whether climate changed driven impacts to listed and at-risk species will likely affect installation resilience. Army decision makers should consider using the results to assess the relative vulnerability of installations, identify where additional more detailed vulnerability assessments might need to be conducted, and integrate climate change considerations into the BRAC process. 


\section{Appendix A: Installation Subfactor Values}




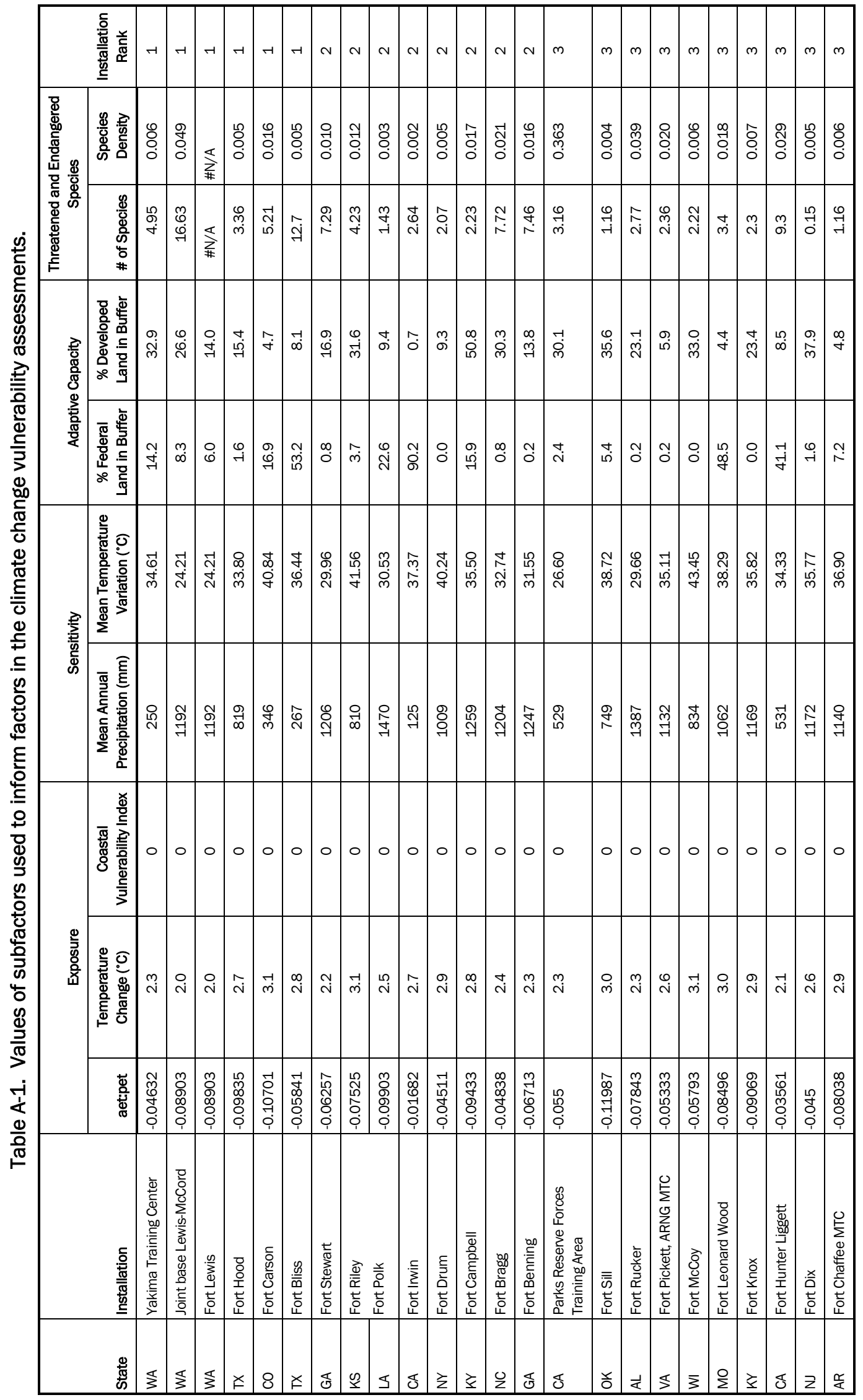




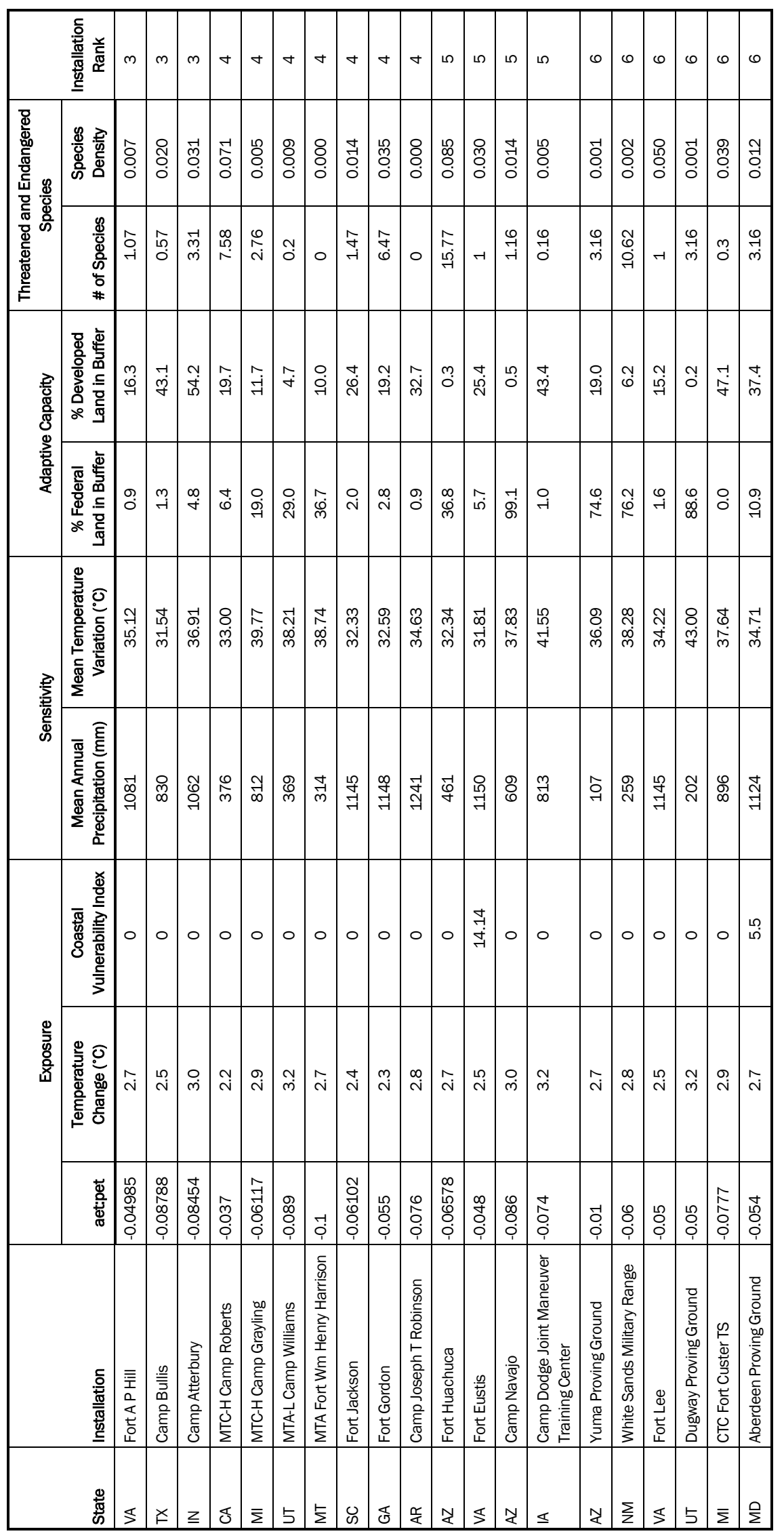


THIS PAGE INTENTIONALLY LEFT BLANK 


\section{Appendix B: Lists of Threatened, Endangered, and At-Risk Species by Installation}




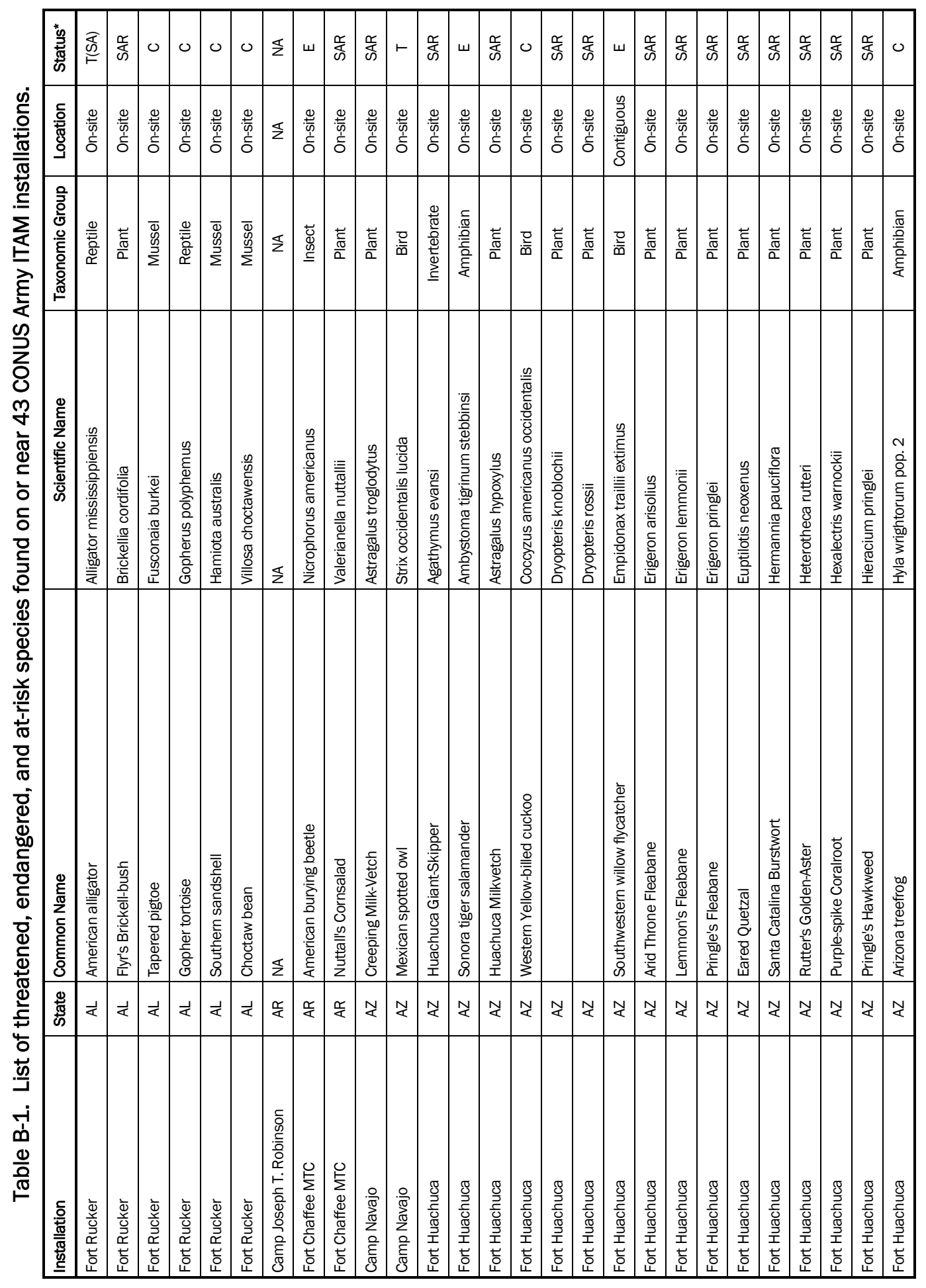

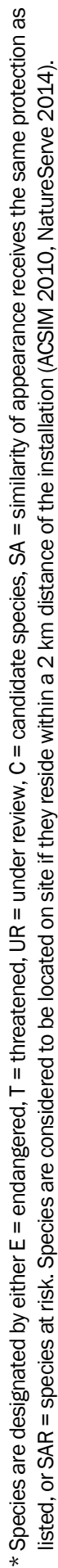




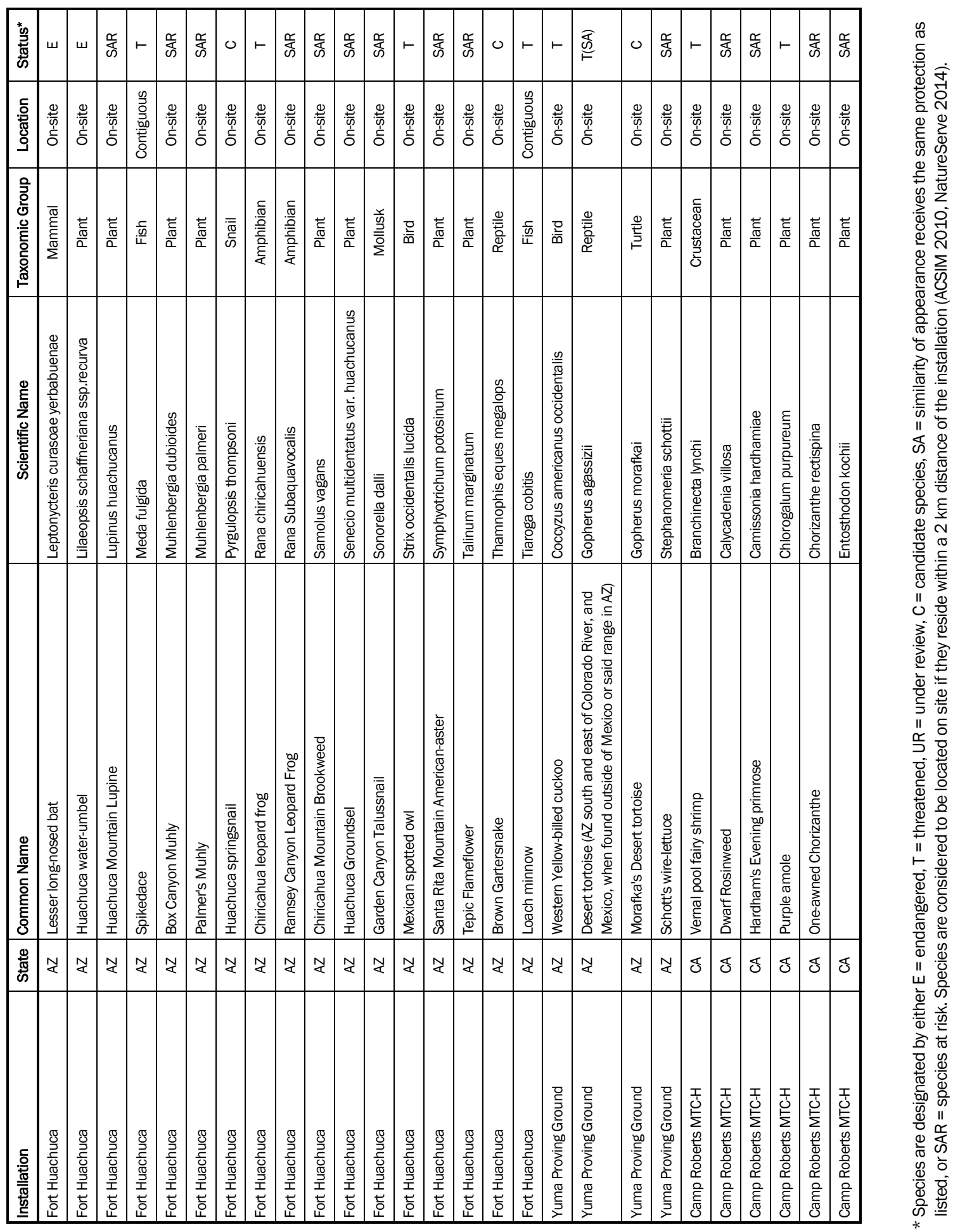




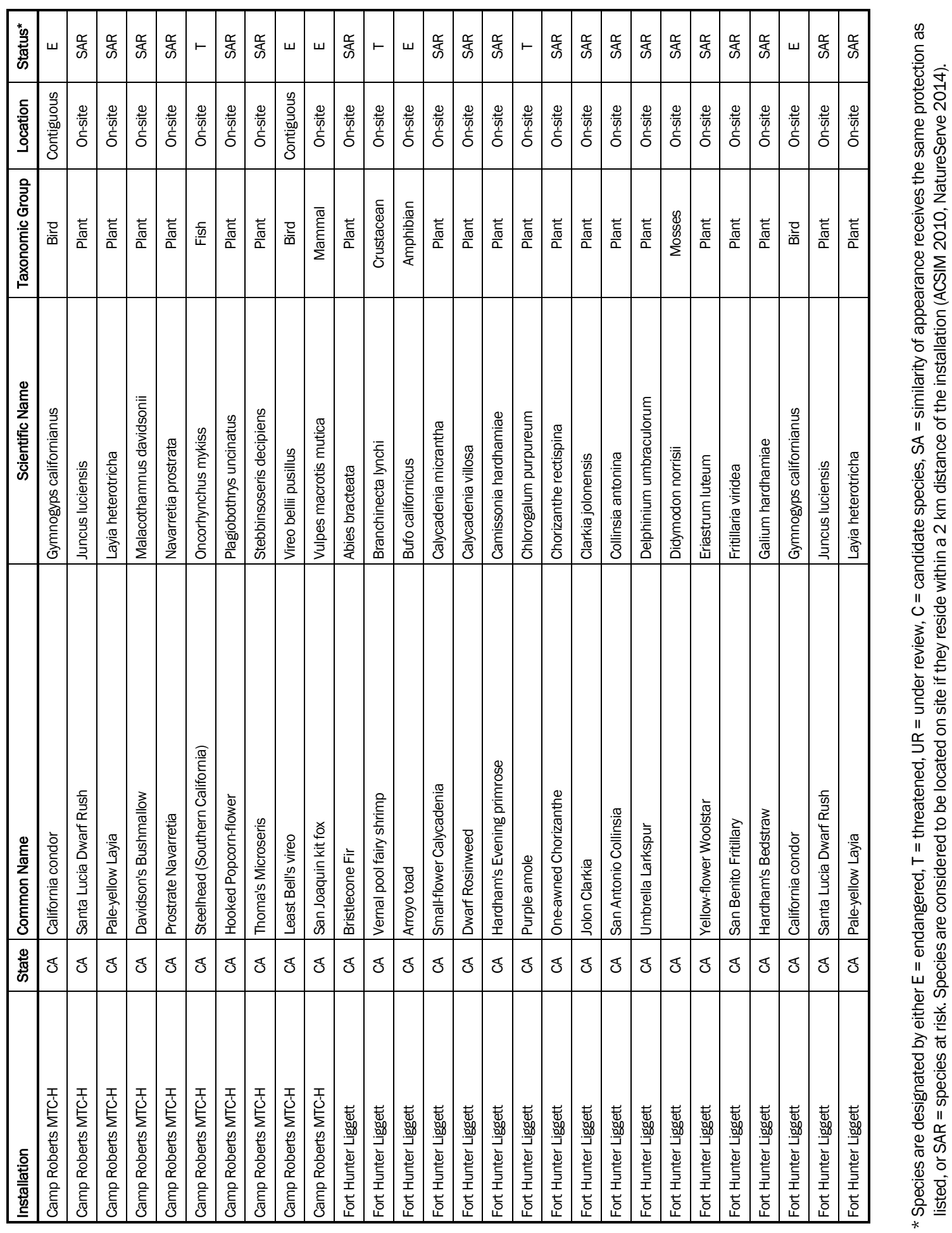




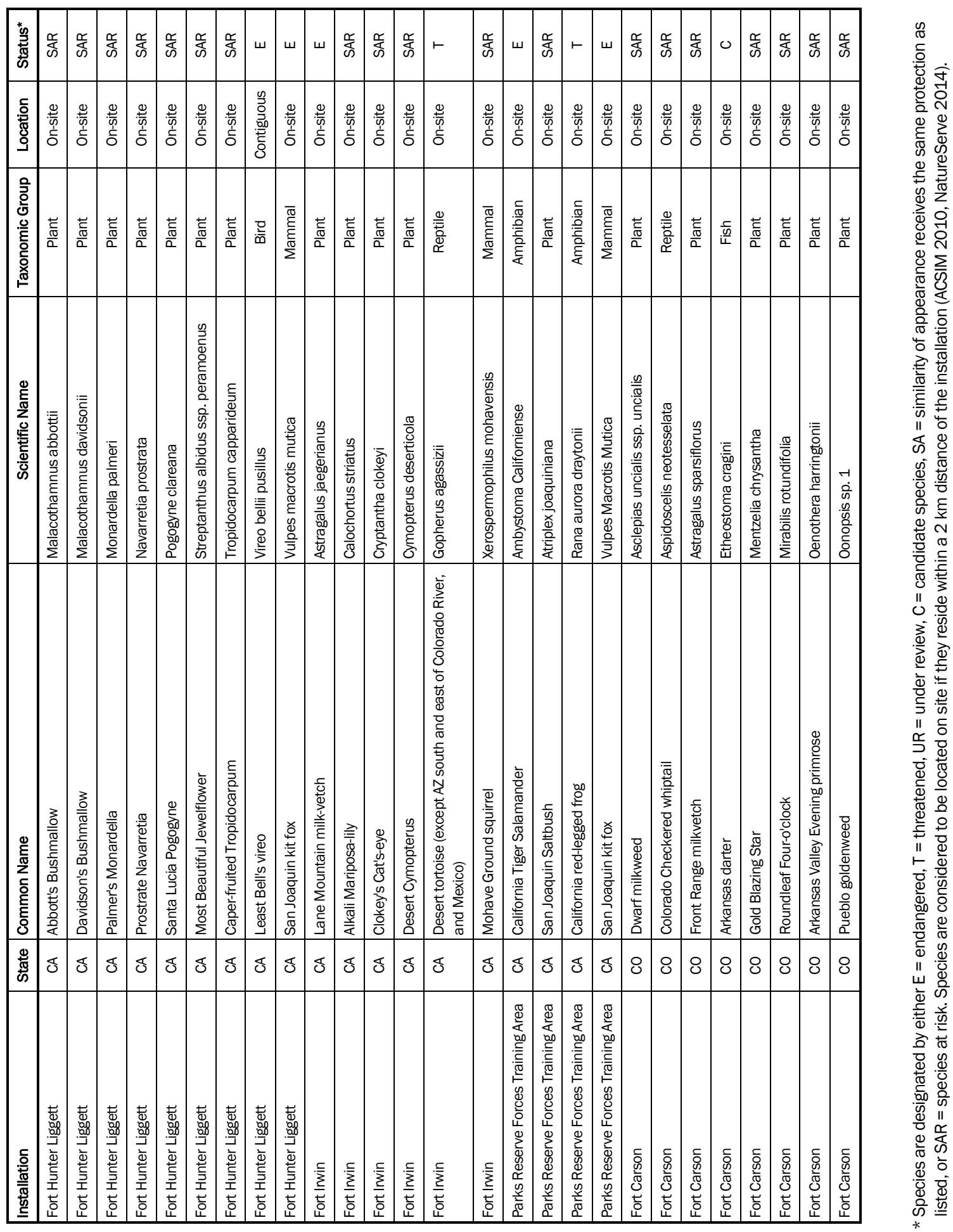




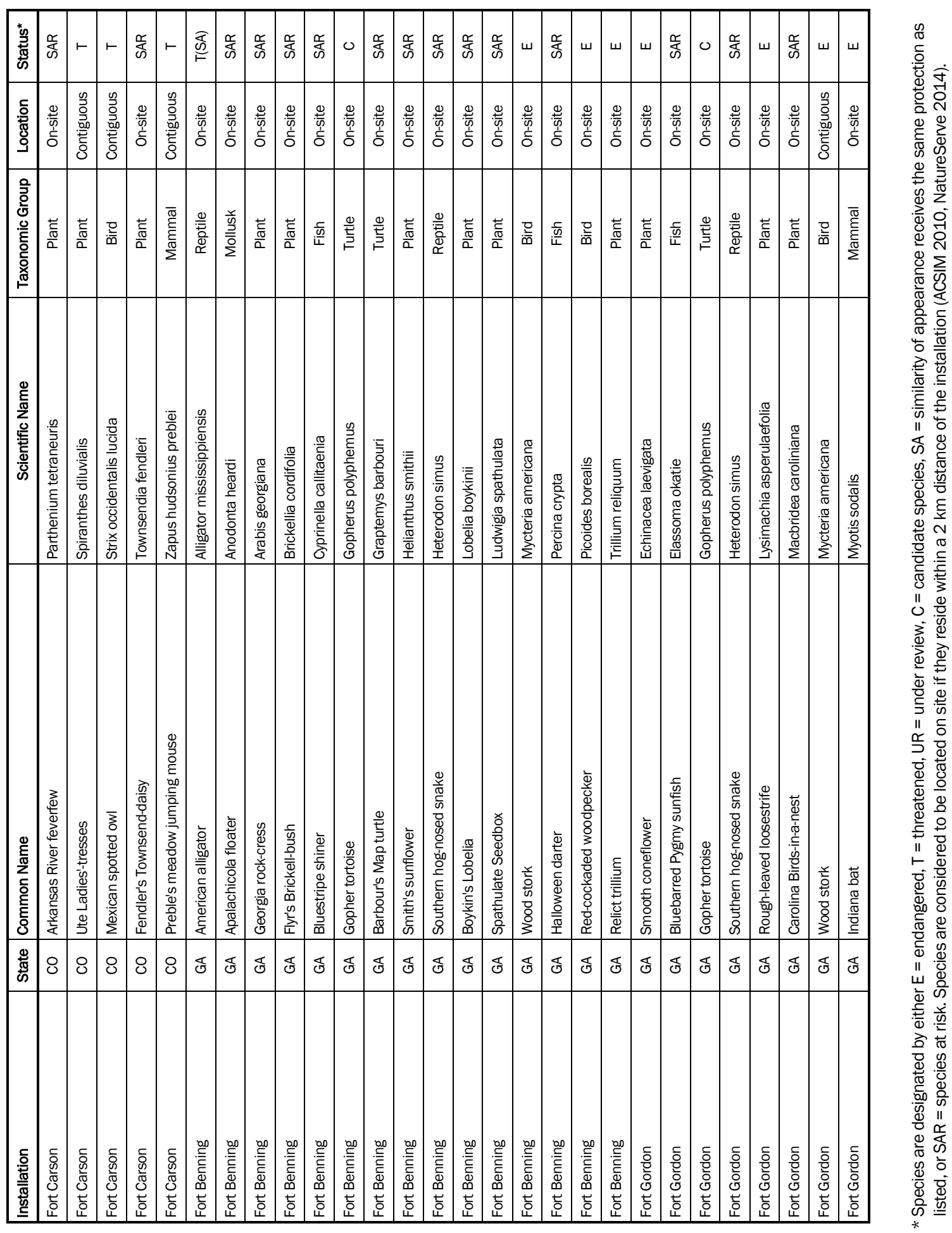




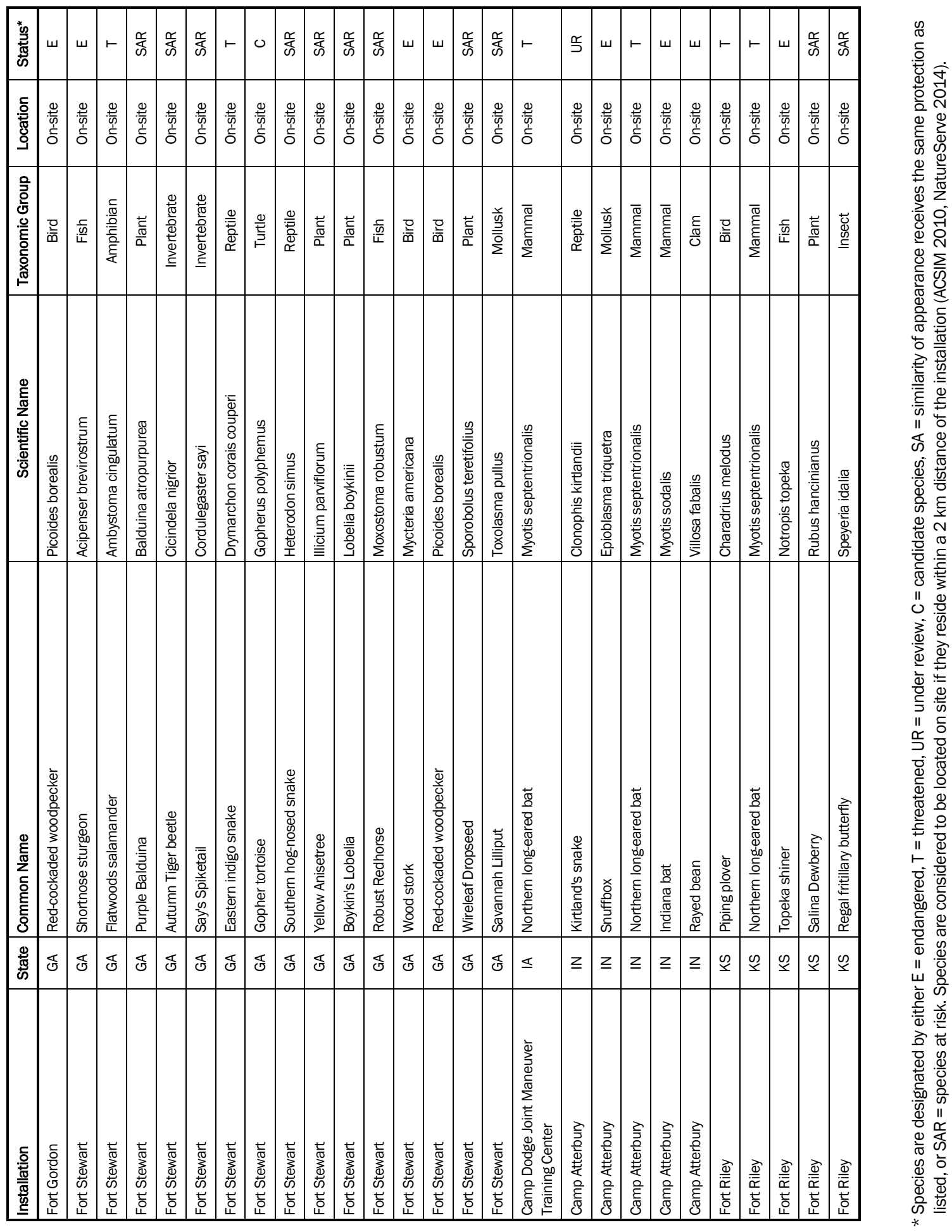




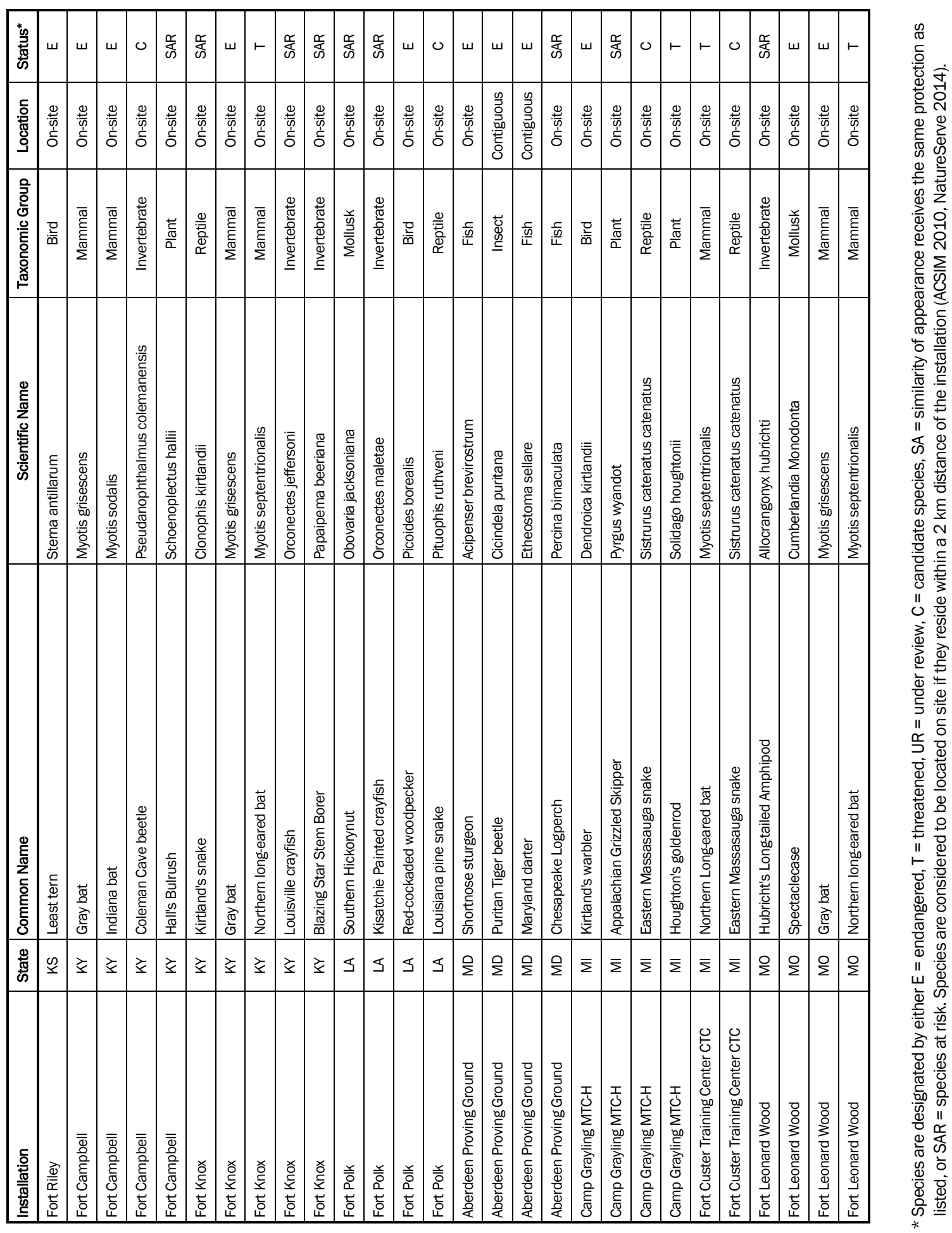




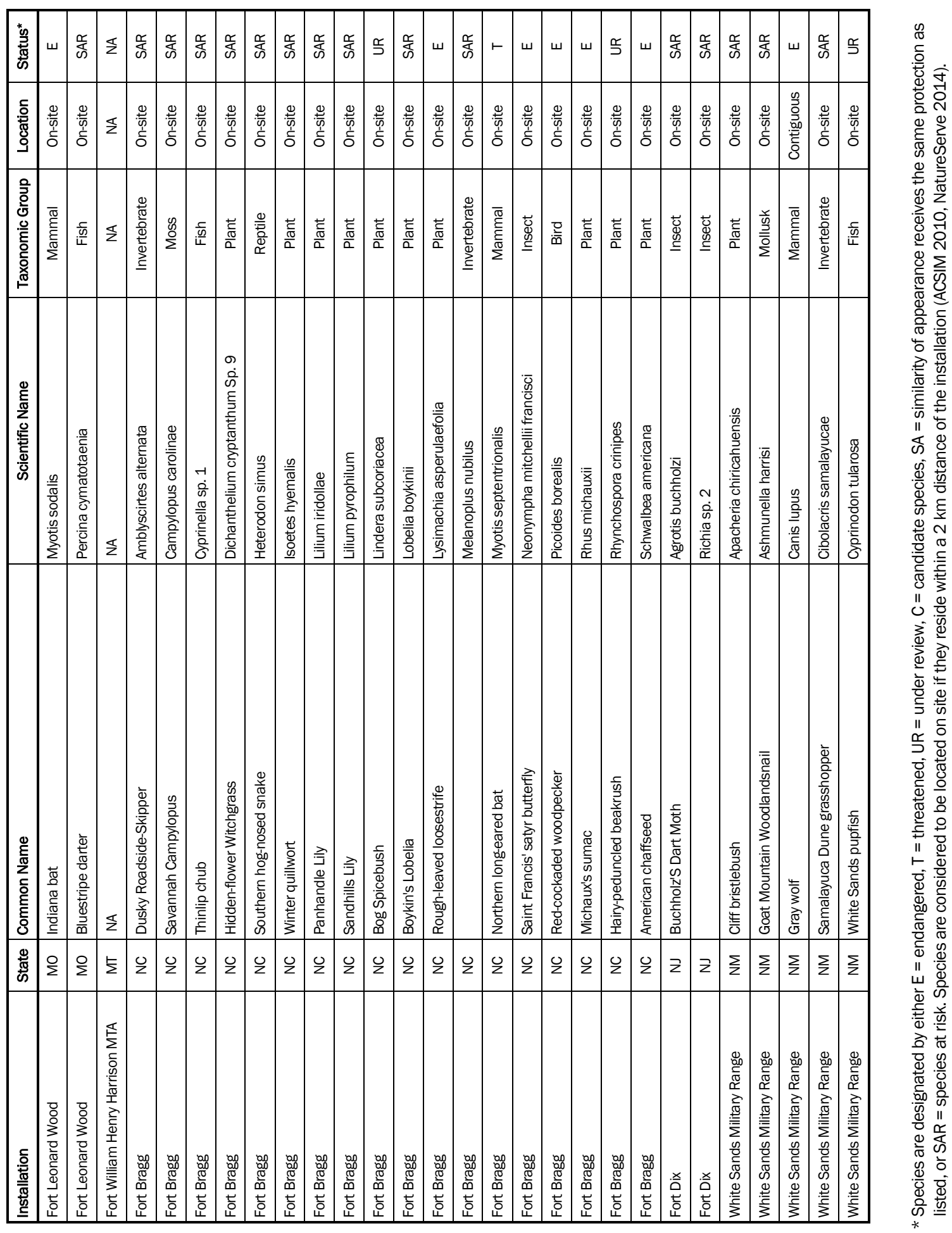




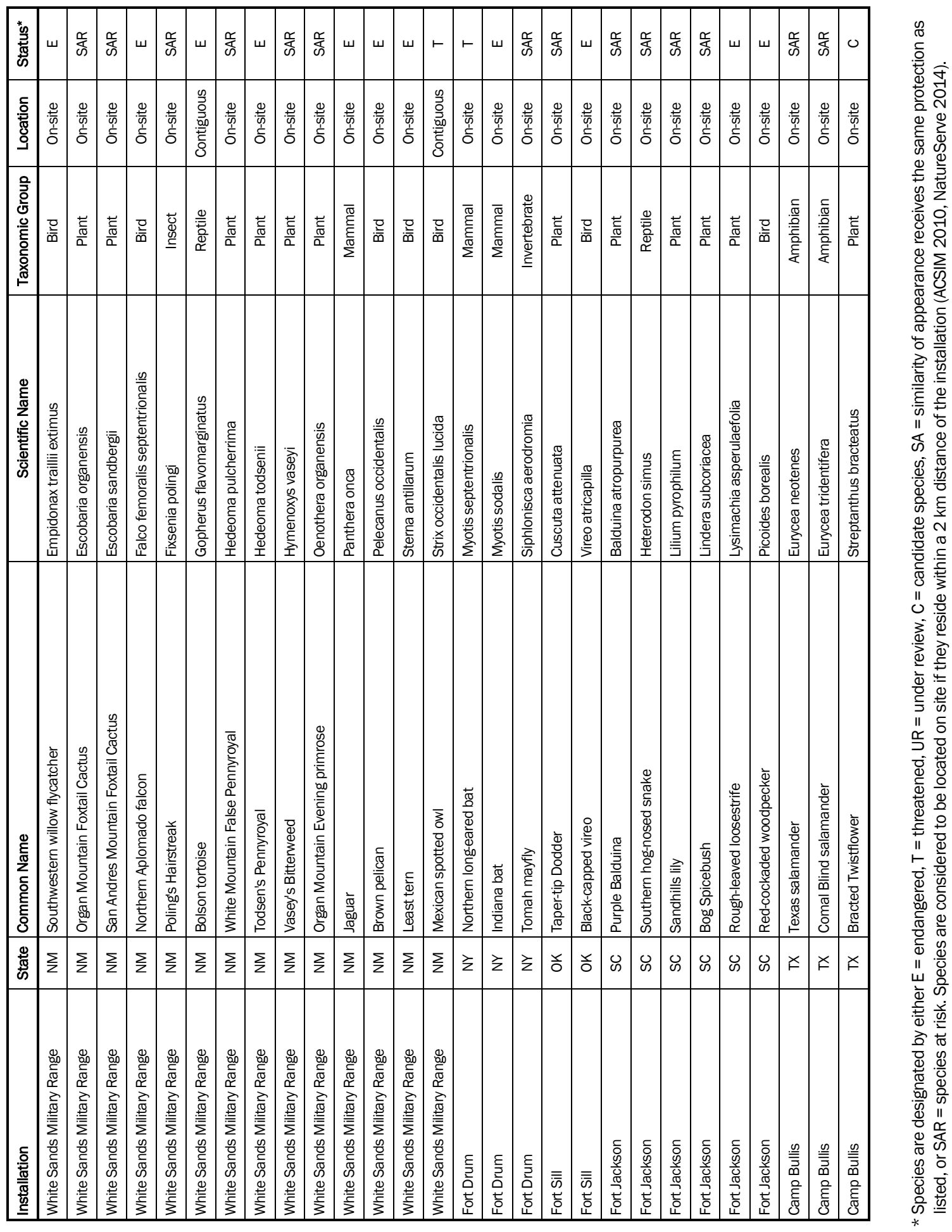




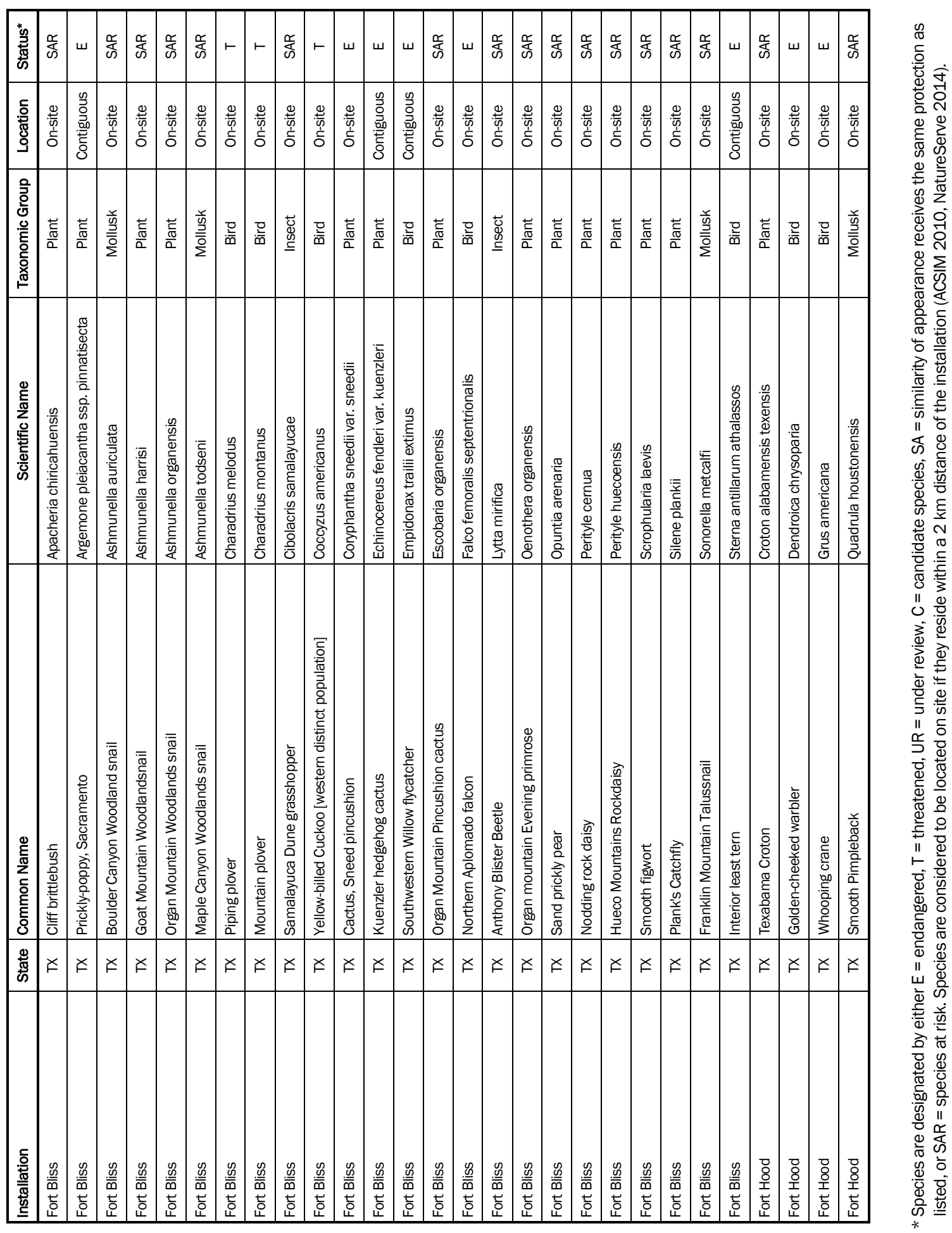




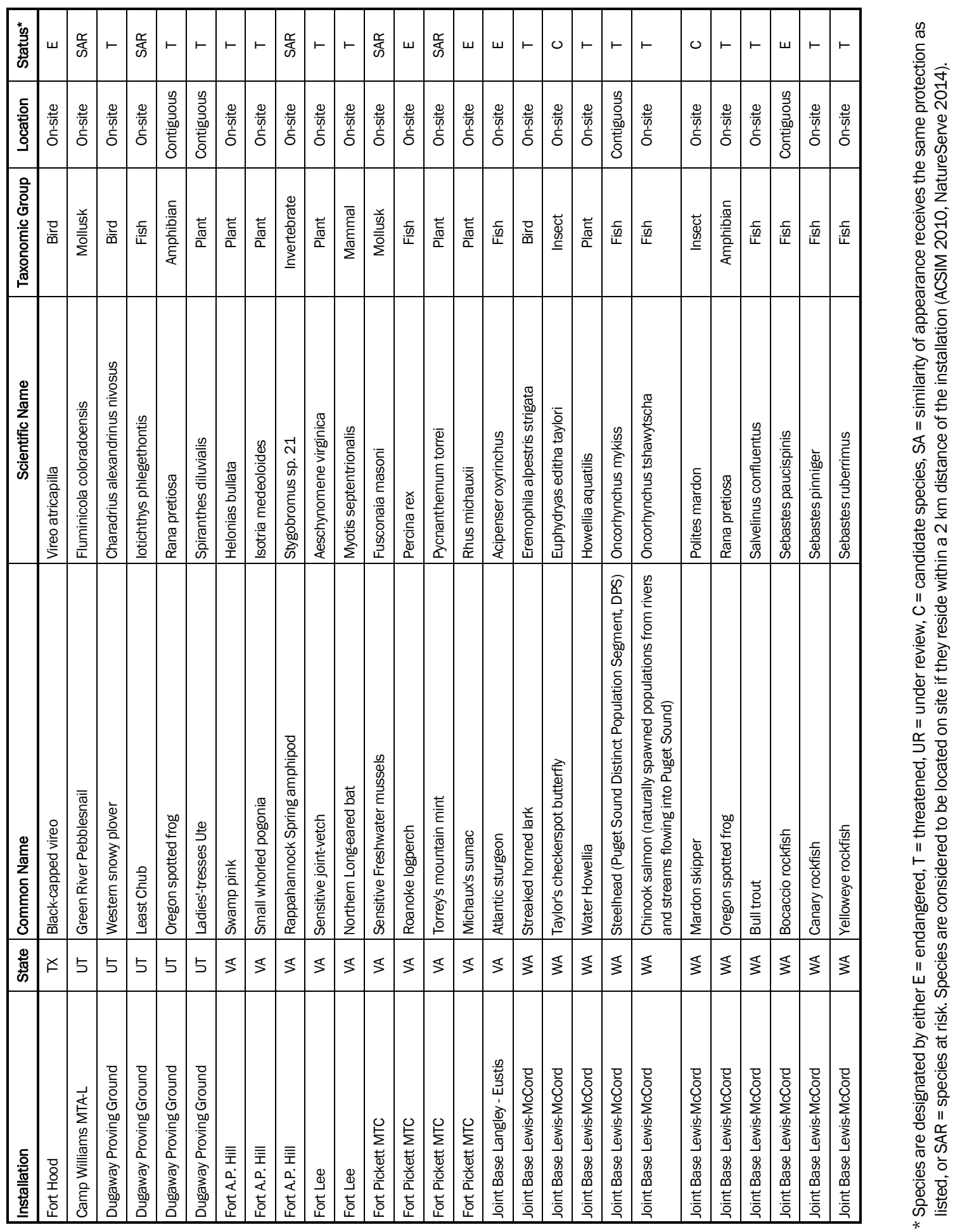



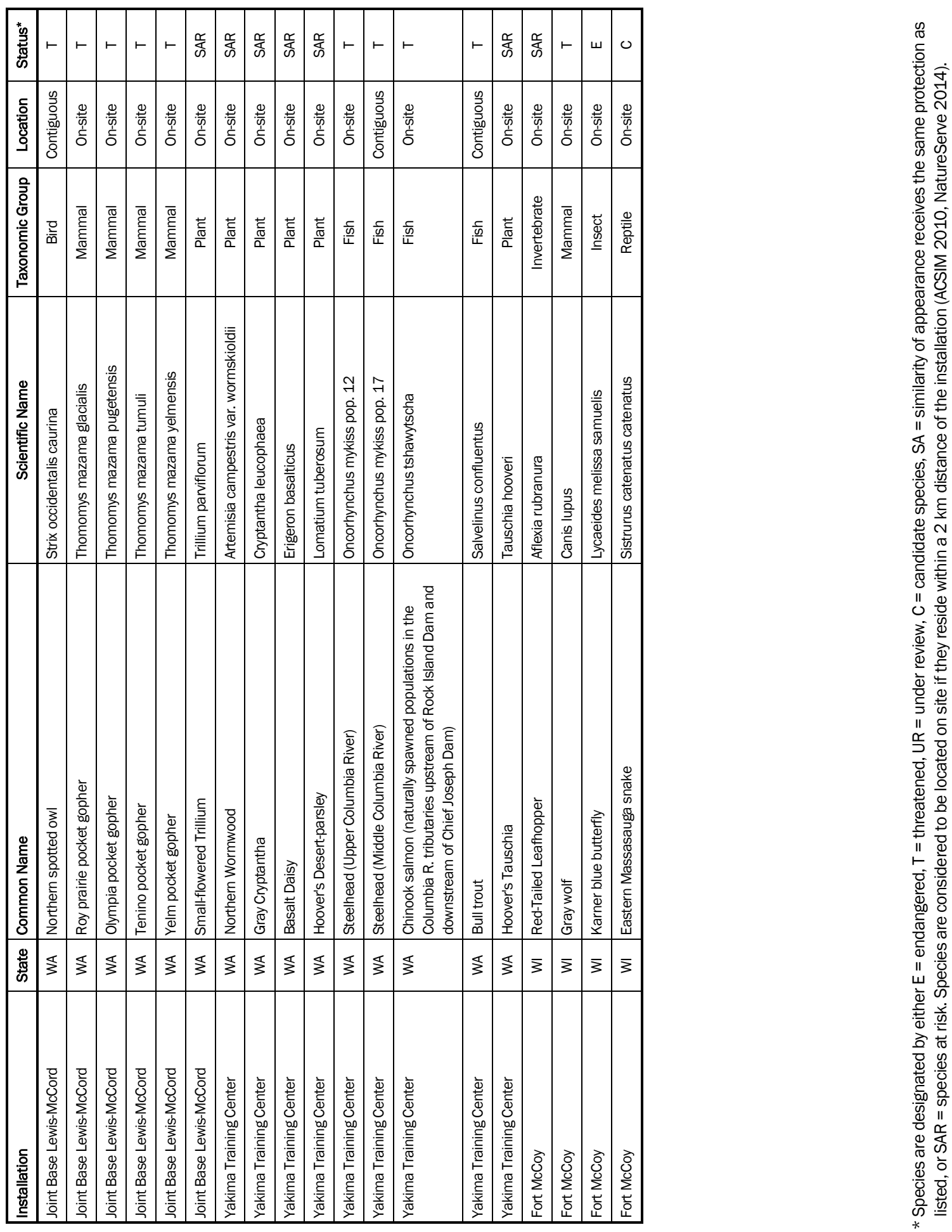


\section{Appendix C: Installation Vulnerabilities Calculated Without the Installation Rank Factor}

Table C-1. Climate change vulnerability scores for 43 CONUS ITAM installations based on four factors, excluding the installation rank factor. Installations are ordered high-to-low based on vulnerability. Blue $=$ minimum, white $=$ median $\left(50^{\text {th }}\right.$ percentile $)$, red $=$ maximum, and transitional colors represent intermediate percentiles.

\begin{tabular}{|l|l|c|}
\hline Installation & State & Vulnerability \\
\hline Parks Reserve Forces Training Area & CA & 1.047 \\
\hline Joint base Lewis-McCord & WA & 0.953 \\
\hline Fort Huachuca & AZ & 0.935 \\
\hline Fort Bliss & TX & 0.751 \\
\hline Camp Atterbury & IN & 0.730 \\
\hline MTC-H Camp Roberts & CA & 0.720 \\
\hline Fort Carson & CO & 0.688 \\
\hline Fort Bragg & NC & 0.663 \\
\hline Fort Sill & OK & 0.660 \\
\hline Fort Eustis & VA & 0.659 \\
\hline Fort Riley & KS & 0.656 \\
\hline White Sands Military Range & NM & 0.653 \\
\hline CTC Fort Custer TS & MI & 0.646 \\
\hline Camp Bullis & TX & 0.643 \\
\hline Yakima Training Center & WA & 0.638 \\
\hline Fort Campbell & KY & 0.637 \\
\hline Aberdeen Proving Ground & MD & 0.637 \\
\hline Fort Hood & TX & 0.634 \\
\hline Fort Benning & GA & 0.626 \\
\hline Fort Gordon & GA & 0.620 \\
\hline Fort Stewart & GA & 0.619 \\
\hline Camp Dodge Joint Maneuver Training Center & IA & 0.603 \\
\hline Fort Hunter Liggett & CA & 0.594 \\
\hline Fort Knox & KY & 0.588 \\
\hline Fort Rucker & AL & 0.573 \\
\hline Fort McCoy & WI & 0.567 \\
\hline MTA-L Camp Williams & UT & 0.550 \\
\hline Camp Joseph T Robinson & AR & 0.528 \\
\hline MTC-H Camp Grayling & MI & 0.511 \\
\hline Fort Jackson & SC & 0.510 \\
\hline
\end{tabular}




\begin{tabular}{|l|l|c|}
\hline Installation & State & Vulnerability \\
\hline Fort Leonard Wood & MO & 0.502 \\
\hline MTA Fort Wm Henry Harrison & MT & 0.501 \\
\hline Fort Lee & VA & 0.496 \\
\hline Fort Chaffee MTC & AR & 0.486 \\
\hline Fort Dix & NJ & 0.482 \\
\hline Fort Pickett, ARNG MTC & VA & 0.477 \\
\hline Fort A P Hill & VA & 0.473 \\
\hline Fort Drum & NY & 0.472 \\
\hline Fort Polk & LA & 0.465 \\
\hline Yuma Proving Ground & AZ & 0.463 \\
\hline Dugway Proving Ground & UT & 0.435 \\
\hline Camp Navajo & AZ & 0.410 \\
\hline Fort Irwin & CA & 0.378 \\
\hline
\end{tabular}




\section{References}

Abatzoglou, J . T., and C. A. Kolden. 2011. Climate change in western US deserts: Potential for increased wildfire and invasive annual grasses. Rangeland Ecology and Management 64:471-478.

Assistant Chief of Staff for Installation Management (ACSIM). 2010. Threatened, Endangered, and at-Risk Species Interagency Research Coordination Manual, http://www.dodnaturalresources.net/files/TER-S_Interagency_Research_Coordination_Manual.pdf

Bagne, K. E., M. M. Friggens, and D. M. Finch. 2011. A System for Assessing Vulnerability of Species (SAVS) To Climate Change. General Technical Report RMRS-GTR-257. Fort. Collins, CO: U.S. Department of Agriculture, Forest Service, Rocky Mountain Research Station.

Bierwagen, Britta, and Phil Morefield. 2014. Integrated Climate and Land Use Scenarios (ICLUS). Accessed September 25, http://134.67.99.51/ICLUSonline/

Cox, W. A., F. R. Thompson III, and J . L. Reidy. 2013. The Effects of temperature on nest predation by mammals, birds, and snakes. The Auk 130:784-790. doi: http://dx.doi.org/10.1525/auk.2013.13033

Dawson, T. P., S. T. J ackson, J . I. House, I. C. Prentice, and G. M. Mace. 2011. Beyond predictions: Biodiversity conservation in a changing climate. Science 332:53-58.

Deal, B., and V. Pallathucheril. 2009. A use-driven approach to large-scale urban modelling and planning support. Planning Support Systems Best Practice and New Methods, pp 29- 51. Springer Netherlands, http://link.springer.com.proxy2.library.illinois.edu/chapter/10.1007/978-1-4020-8952-7_2

Eastman, J. R., P. A. K. Kyem, J. Toledano, and W. J in. 1993. GIS and Decision Making. Geneva: UNITAR.

Ellenwood, M. S., L. Dilling, and J.B. Milford. 2012. Managing United States public lands in response to climate change: A view from the ground up. Environmental Management 49:954-967.

Environmental Systems Research Institute, Inc. (ESRI). 2016. ArcGIS 10.2.2 (ESRI, Inc., Redlands, CA).

Hellmann, J . J ., J . E. Byers, B. G. Bierwagen, and J . S. Dukes. 2008. Five potential consequences of climate change for invasive species. Conservation Biology 22:534543.

Hohmann, M. G., and W. A. Wall. 2017. Multiscale Assessment of Listed and At-Risk Species: Climate Change Vulnerabilities. ERDC/CERL TR-17-21. Champaign, IL: Engineer Research and Development Center, Construction Engineering Research Laboratory (ERDC-CERL). 
Homer, C. G., J . A. Dewitz, L. Yang, S. J in, P. Danielson, G. Xian, J . Coulston, N.D. Herold, J.D. Wickham, and K. Megown. 2015, Completion of the 2011 National Land Cover Database for the conterminous United States-Representing a decade of land cover change information. Photogrammetric Engineering and Remote Sensing 81:345-354.

J anzen, F. J . 1994. Climate change and temperature-dependent sex determination in reptiles. Proceedings of the National Academy of Sciences 91:7487-7490.

J enkinsa, C. N., K. S. Van Houtanb, S. L. Pimm, and J . O. Sexton. 2015. US protected lands mismatch biodiversity priorities. Proceedings of the National Academy of Science 112:5081-5086.

Kirkwood, C. W. 1997. Strategic Decision Making: Multiobjective Decision Analysis with Spreadsheets. Belmont, CA: Brooks/ Cole, Cengage Learning.

Krasting, J . P., J . P. Dunne, R. J . Stouffer, and R. W. Hallberg. 2016. Enhanced Atlantic sea-level rise relative to the Pacific under high carbon emission rates. Nature Geoscience 9:210-214.

Loarie, S. R., P. B. Duffy, H. Hamilton, G. P. Asner, C. B. Field, and D. D. Ackerly. 2009. The velocity of climate change. Nature 462:1052-1057. doi:10.1038/ nature08649

Malczewski, J . 2000. On the use of weighted linear combination method in GIS: Common and best practice approaches. Transactions in GIS 4:5-22.

Martinuzzi, S., V. C. Radeloff, L. N. J oppa, C. M. Hamilton, D. P. Helmers, A. J . Plantinga, and D. J . Lewis. 2015. Scenarios of future land use change around US protected areas. Biological Conservation 184:446-455.

Messer, K. D., M. Kecinski, Z. Liu, M. A. Korch, and T. Bounds. 2016. Military readiness and environmental protection through cost-effective land conservation. Land Economics 92:433-449.

NatureServe. 2014. Species at Risk on Department of Defense Lands: Updated Analysis, Report and Maps. DoD Legacy Project 10-247.

Ordonez, A., S. Martinuzzi, V. Radeloff, and J . W. Williams. 2014. Combined speeds of climate and land-use change of the conterminous US until 2050. Nature Climate Change 4:811-816.

Shaw, M. R., K. Klausmeyer, D. R. Cameron, J . Mackenzie, and P. Roehrdanz. 2012. Economic costs of achieving current conservation goals in the future as climate changes. Conservation Biology 26:385-396.

Sperry, J . H., W. A. Wall, and M. G. Hohmann. 2016. Evaluation of 757 Species Under U.S. Endangered Species Act Review on Department of Defense Lands and Their Potential Impact on Army Training. ERDC/ CERL TR-16-3. Champaign, IL: ERDC-CERL.

Stein, B. A., C. Scott, and N. Benton. 2008. Federal lands and endangered species: The role of military and other federal lands in sustaining biodiversity. BioScience 58:339-347. 
Thieler, E. R., and E. S. Hammar-Klose. 2000. National Assessment of Coastal Vulnerability to Sea-Level Rise: Preliminary Results for the U.S. Atlantic Coast. U.S. Geological Survey Open-File Report 99-593.

Tomanek, L. 2008. The importance of physiological limits in determining biogeographical range shifts due to global climate change: The heat-shock response. Physiological and Biochemical Zoology 81:709-717.

Urban, M. C. 2015. Accelerating extinction risk from climate change. Science 348:571573.

U.S. Department of Defense (DoD). 2010. Quadrennial Defense Review. Washington, DC: DoD, http://www.defense.gov/Portals/1/features/defenseReviews/QDR/QDR_as_of_29JAN10_1600.pdf

2011. DoD Instruction (DODI) 4715.03. Subject: DoD Instruction. Washington, DC: Office of the Under Secretary of Defense, Acquisition, Technology and Logistics (OUSD[AT\&L]), http://www.dtic.mil/whs/directives/corres/pdf/471503p.pdf

_. 2012. 2012 Climate Change Adaptation Roadmap. Washington, DC: DoD.

— 2013. U.S. Department of Defense Manual. Subject: Integrated Natural Resources Management Plan (INRMP) Implementation Manual. DODM 4715.03. Washington, DC: OUSD(AT\&L), http://www.dtic.mil/whs/directives/corres/pdf/471503m.pdf

2014a. 2014 Climate Change Adaptation Roadmap. Washington, DC: DoD, http://reliefweb.int/sites/reliefweb.int/files/resources/CCARprint.pdf

U.S. Environmental Protection Agency (USEPA). 2009. A Framework for Categorizing the Relative Vulnerability of Threatened and Endangered Species to Climate Change. EPA/ 600/R-09/011. Washington, DC: National Center for Environmental Assessment, available from the National Technical Information Service, Springfield, VA and online at http://www.epa.gov/ncea.

U.S. Government Accountability Office (GAO). 2009. Climate Change Adaptation: Strategic Federal Planning Could Help Government Officials Make More Informed Decisions. GAO-10-113. Washington, DC: GAO.

- 2014. Climate Change Adaptation: DoD Can Improve Infrastructure Planning and Process to Better Account for Potential Impacts. GAO-14-446. Washington, DC: GAO, http://www.gao.gov/assets/670/663734.pdf

- 2014. Climate Change Adaptation: DOD Can Improve Infrastructure Planning and Process to Better Account for Potential Impacts. GAO-14-446, 58 pp.

Vale, C. G., and J . C. Brito. 2015. Desert-adapted species are vulnerable to climate change: Insights from the warmest region on Earth. Global Ecology and Conservation 4:369-379.

Westervelt, J., T. BenDor, and J . Sexton. 2011. A technique for rapidly forecasting regional urban growth. Environment and Planning B: Planning and Design 38:61- 81. doi:10.1068/ b36029. 
White House, The. 2009. Federal Leadership in Environmental, Energy and Economic Performance. Executive Order (EO) 13514. Washington, DC: The White House, Office of the Press Secretary, https://www.whitehouse.gov/the-press-office/presidentobama-signs-executive-order-focused-federal-leadership-environmental-ener

White House, The. 2013. Preparing the United States for the Impacts of Climate Change. EO 13653. Washington, DC: The White House, Office of the Press Secretary, https://www.whitehouse.gov/the-press-office/2013/11/01/executive-order-preparing-unitedstates-impacts-climate-change

Wilhoit, J ., S. Tweddale, M. G. Hohmann, D. Delaney, M. E. Swearingen, and J . Westervelt. 2015. Effects of Climate Change, Urban Development and Threatened and Endangered Species Management on Army Training Capabilities. ERDC/ CERL TR-16-29. Champaign, IL: ERDC-CERL.

Williams, S. E., L. P. Shoo, J . L. Isaac, A. A. Hoffmann, and G. Langham. 2008. Towards an integrated framework for assessing the vulnerability of species to climate change. PLoS Biol 6(12):e325. doi:10.1371/journal.pbio.0060325.

Wilson, T. S., B. M. Sleeter, R. R. Sleeter, and C. E. Soulard. 2014. Land-use threats and protected areas: A scenario-based, landscape level approach. Land 3:362-389. doi:10.3390/land3020362.

Young, B. E., N. S. Dubois, and E. L. Rowland. 2014. Using the Climate Change Vulnerability Index to inform adaptation planning: Lessons, innovations, and next steps. Wildlife Society Bulletin DOI:10.1002/ wsb.478.

Young, B. E., E. Byers, G. Hammerson, A. Frances, L. Oliver, and A. Treher. 2015. Guidelines for Using the NatureServe Climate Change Vulnerability Index. Release 3.0, Arlington VA, 63 pp. 


\section{Acronyms and Abbreviations}

\begin{tabular}{|c|c|}
\hline $\begin{array}{l}\text { Term } \\
\text { ACSIM }\end{array}$ & $\begin{array}{l}\text { Definition } \\
\text { Assistant Chief of Staff for Installation Management }\end{array}$ \\
\hline ACUB & Army Compatible Use Buffer \\
\hline AET:PET & Actual Evapotranspiration Potential Evapotranspiration \\
\hline ANSI & American National Standards Institute \\
\hline $\operatorname{ASA}(A L T)$ & $\begin{array}{l}\text { Office of the Assistant Secretary of the Army for Acquisition, Logistics, } \\
\text { and Technology }\end{array}$ \\
\hline BRAC & Base Realignment and Closure \\
\hline CCAR & Climate Change Adaptation Roadmap \\
\hline CEERD & $\begin{array}{l}\text { US Army Corps of Engineers, Engineer Research and Development } \\
\text { Center }\end{array}$ \\
\hline CERL & Construction Engineering Research Laboratory \\
\hline CONUS & Continental United States \\
\hline CTC & Combat Training Center \\
\hline DoD & U.S. Department of Defense \\
\hline DODI & Department of Defense Instruction \\
\hline DODM & Department of Defense Manual \\
\hline EO & Executive Order \\
\hline ERDC & U.S. Army Engineer Research and Development Center \\
\hline ERDC-CERL & $\begin{array}{l}\text { Engineer Research and Development Center, Construction Engineering } \\
\text { Research Laboratory }\end{array}$ \\
\hline ESA & U.S. Endangered Species Act \\
\hline ESRI & Environmental Systems Research Institute, Inc. \\
\hline ICLUS & Integrated Climate and Land Use Scenarios \\
\hline INRMP & Integrated Natural Resources Management Plans \\
\hline ITAM & Integrated Training Area Management \\
\hline LEAM & Land-use Evolution and impact Assessment Model \\
\hline MTA & Military Training Area \\
\hline MTA-L & Military Training Area-Light \\
\hline MTC & Military Training Center \\
\hline MTC-H & Military Training Center-Heavy \\
\hline NSN & National Supply Number \\
\hline OACSIM & Office of the Assistant Chief of Staff for Installation Management \\
\hline OMB & Office of Management and Budget \\
\hline $\mathrm{PO}$ & Post Office \\
\hline REPI & Readiness and Environmental Protection Integration \\
\hline RUG & Regional Urban Growth (model) \\
\hline SAR & Same As Report \\
\hline TS & Training Support \\
\hline USEPA & U.S. Environmental Protection Agency \\
\hline
\end{tabular}


Term Definition

USFWS US Fish and Wildlife Service

USGS U.S. Geological Survey 


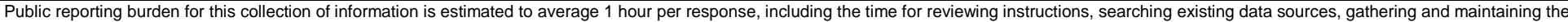

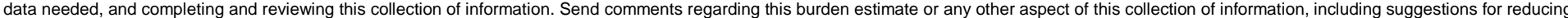

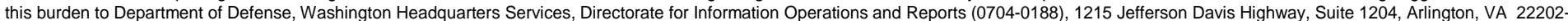

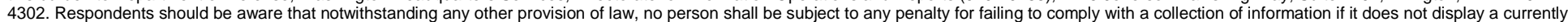
valid OMB control number. PLEASE DO NOT RETURN YOUR FORM TO THE ABOVE ADDRESS
1. REPORT DATE (DD-MM-YYYY)
2. REPORT TYPE
$07 / 12 / 2017$
Final

\section{TITLE AND SUBTITLE}

Climate Change Vulnerability of Army Installations Attributable to Listed and At-Risk Species

6. AUTHOR(S)

Matthew G. Hohmann, David K. Delaney, and Wade A. Wall

U.S. Army Engineer Research and Development Center (ERDC)

Construction Engineering Research Laboratory (CERL)

PO Box 9005,

Champaign, IL 61826-9005

3. DATES COVERED (From - To)

\section{5a. CONTRACT NUMBER}

5b. GRANT NUMBER

5c. PROGRAM ELEMENT

622720A896

5d. PROJECT NUMBER

5e. TASK NUMBER

5f. WORK UNIT NUMBER

F94KF0

8. PERFORMING ORGANIZATION REPORT NUMBER

ERDC/ CERL TR-17-22

\section{SPONSORING I MONITORING AGENCY NAME(S) AND ADDRESS(ES)}

Office of the Assistant Secretary of the Army for Acquisition, Logistics, and Technology 103 Army Pentagon

Washington, DC 20310-0103

D. SPONSOR/MONITOR'S ACRONYM(S)

OACSIM-ISE

11. SPONSOR/MONITOR'S REPORT NUMBER(S)

\section{DISTRIBUTION I AVAILABILITY STATEMENT}

Approved for public release; distribution is unlimited.

\section{SUPPLEMENTARY NOTES}

\section{ABSTRACT}

Climate change is an important emerging concern for the U.S. Department of Defense (DoD) and the Army. Key among the issues is climate change-driven increases in the number of species listed under the U.S. Endangered Species Act (ESA) and stress to Federally listed species already listed, because both pose additional management requirements and challenges, as well as potential restrictions on training land use. This work developed an approach for characterizing this component of installation climate change vulnerability that integrates multiple factors related to exposure, sensitivity, adaptive capacity, and number of listed and at-risk species. The approach was applied to Army installations in the Continental United States that have Integrated Training Area Management (ITAM) programs. Additionally, the assessment was used to rank installations across the Army based on the aggregate vulnerabilities of species. The approach to vulnerability assessment demonstrated here is suitable for evaluating whether climate change-driven impacts to listed and atrisk species is likely to affect installation resilience.

\section{SUBJECT TERMS}

Endangered species--United States, Military bases, Climatic changes, Climatic changes--Risk assessment, Environmental management

\section{SECURITY CLASSIFICATION OF:}

\begin{tabular}{l}
\hline a. REPORT \\
Unclassified
\end{tabular}

NSN 7540-01-280-5500

\section{b. ABSTRACT}

Unclassified

\section{c. THIS PAGE}

Unclassified

17. LIMITATION
OF ABSTRACT
SAR

18. NUMBER OF PAGES

60 19a. NAME OF RESPONSIBLE PERSON

19b. TELEPHONE NUMBER

(include area code) 